This is the accepted version of the following article: Villen-Guzman, M., Arhoun, B., Vereda-Alonso, C., Gomez-Lahoz, C., Rodriguez-Maroto, J.M. and Paz-Garcia, J.M. (2019), Electrodialytic processes in solid matrices. New insights into battery recycling. A review. J. Chem. Technol. Biotechnol., 94: 1727-1738. doi:10.1002/jctb.5940, which has been published in final form at https:/onlinelibrary.wiley.com/action/ showCitFormats?doi=10.1002\%2Fjctb.5940. This article may be used for non-commercial purposes in accordance with the Wiley Self-Archiving Policy [http://www.wileyauthors.com/self-archiving]. 


\title{
Electrodialytic processes in solid matrices. New insights into batteries recycling. A review.
}

Short title: New insights into Lithium-Ion batteries recycling.

Maria Villen-Guzman*, Brahim Arhoun, Carlos Vereda-Alonso, Cesar Gomez-Lahoz, Jose M. Rodriguez-Maroto, Juan M. Paz-Garcia

Chemical Engineering Department, Faculty of Sciences; University of Malaga. 29071Malaga. Spain.

*corresponding author: mvillen@uma.es. +34952133449

\begin{abstract}
Electrodialytic Remediation has been widely applied to the recovery of different contaminants from numerous solid matrices solving emerging issues of environmental concern. Results and conclusions reported in studies about real contaminated matrices are summarizes in this work. The influence of the $\mathrm{pH}$ value on the treatment effectiveness has been widely proved highlighting the phenomenon "water splitting" in the membrane surface. This dissociation of water molecules is related to the "limiting current" which is desirable to be exceed at the Anion Exchange Membrane in order to produce the entering of protons toward solid matrix. Other important parameters for the optimization of the technique, such as the current density and the liquid to solid ratio, are also discussed through the revision of studies using real solid matrices.
\end{abstract}

This work also focusses on the pioneer proposal of electrokinetic technologies for the recycling of lithium ion batteries considering the relevance of waste properties in the design and optimization of the technique. From a thorough literature revision, it could be concluded that further experimental results are needed to allow an optimal 
application of the technique to the rising problem of residues from batteries. The main aim of this work is to take the first steps in the recovery of valuable metals from spent batteries, such as Li and Co, incorporating principles of green chemistry.

\section{Keywords:}

Environmental Remediation; Waste treatment and Waste Minimization; Membranes; Electrochemistry

\section{Introduction}

Electrodialysis (ED) is one of the most relevant membrane methods to separate ionic species from an aqueous solution or other uncharged matrices. ${ }^{1}$ The term "electrodialysis" appeared for the first time in the patent developed by Schollmeyer in 1900. The aim of that work was to purify sugar syrup using ozonation and iron or soluble zinc anode. ${ }^{2}$ However, the principle of the process was previously studied in 1889 by Maigrot and Sabates. ${ }^{3}$ In 1890, Ostwald studied the properties of membranes, discovering that a membrane is impermeable for any electrolyte when it is impermeable for its cations or anions. ${ }^{4}$ By then, the relevant term "membrane potential" was also postulated, referring to the potential at the boundary between the solution and the membrane as a result of the concentration gradient. ${ }^{5}$ In 1940, Meyer and Strauss suggested a multiple compartments ED cell, denoted as membrane stack, using many pairs of alternating anion-selective and cation-selective membranes between two electrodes. ${ }^{6}$ That kind of setup design allows the simultaneous treatment of solutions in many parallel compartments with only a pair of electrodes.

The variety of electrodialysis applications led to the development of membranes with different properties. The desalination of brackish water and seawater, the main application of electrodialysis in the United States and Europe, requires membranes with 
high selectivity and low electro-osmotic permeability. It entails the development of membranes based on heterogeneous structures by the dispersion of a fine ion-exchange resin powder within the solution of a matrix polymer and by the evaporation of the solvent. ${ }^{7}$ Other important use of electrodialysis is the concentration of sodium chloride from seawater to produce table salt. This application involves the development of homogeneous membranes with very low electrical resistance. Although this kind of membrane was first proposed by ionics Inc. in 1951-1953, it was not used at industrial scale until 1975 by the Japanese company Asahi Chemicals. ${ }^{8}$

Besides the desalination of saline solutions, currently the most relevant use at industrial scale of ED, other applications are being developed. Some examples are: purification, modification and concentration of food, ${ }^{1}$ production of organic acids, ${ }^{9}$ desalination of coal-mine brine, ${ }^{10}$ treatment of industrial effluents, ${ }^{11}$ demineralization of whey, ${ }^{12,13}$ production of ultrapure water ${ }^{14}$ and recovery of lithium from brine ${ }^{15}$. The Electrodialytic Remediation (EDR) is a technique that allows the removal of contaminants from soils and solid waste products combining the electrokinetic remediation (EKR) method with electrodialysis.

This work presents the idea of battery recycling via electrodialytic methods. With this aim, the application of EDR is thoroughly discussed paying special attention to the most relevant operating parameters. From the revision of EDR application to different solid matrices together with the analysis of waste properties of spent batteries, the applicability of the technology is evaluated. 


\section{Electrochemical technologies}

\section{Fundamentals of Electrokinetic Remediation}

EKR consists of the application of an electric current between a pair of electrodes to mobilize and extract contaminants, such as toxic metals or organic compounds, from soils and other porous solid matrices. ${ }^{16-18}$ The electric field prompts the transport of species through the porous media by electromigration, electroosmosis and electrophoresis transport mechanisms. ${ }^{16,19,20}$ EKR is recommended for the in situ treatment of low water-permeability solid matrices. A schematic of the EKR process is presented in Figure 1.

Diffusion is the movement of ionic and molecular constituent form of the contaminants due to the gradient of chemical potential. The electromigration transport mechanism, also known as ionic migration, refers to the movement of ionic charged species in the pore fluid towards the electrode of opposite charge. These two strongly coupled transport mechanisms are known as electro-diffusion, and typically defined by the Nernst-Planck transport equation. ${ }^{21}$ Under common conditions for EKR treatments, the electromigration is some orders of magnitude greater than the diffusion. ${ }^{19}$

Another phenomenon that takes places in porous media as a consequence of the application of an electric gradient is the electroosmotic transport. ${ }^{22}$ Most soils have negatively-charged surface, which produces a positively-charged diffuse layer of electrolyte at the solid-electrolyte interface region. Similar to the ionic migration transport, the positively-charged diffused layer flows towards the cathode under applied electric fields, sweeping along the aqueous phase and the dissolved species. Under certain circumstances, such as when the electrolyte concentration is high and the $\mathrm{pH}$ value of the pore fluid is very low, it is possible to reverse the polarity of the surface charge and the electroosmotic can flow from cathode to anode. This phenomenon is 
known as "reverse electroosmosis". Electrophoresis is the movement of charged particles of colloidal size due to the application of an electric potential. This movement can often be neglected when the solid phase is stationary as, for instance, in soils with low permeability. However, if the electric current is applied to slurry, this phenomenon may play an important role. ${ }^{23}$

In addition to these transport processes, the application of the electric field is inherently related to electrolysis reactions at the electrodes: ${ }^{16}$

Oxidation (at the anode):

$$
2 \mathrm{H}_{2} \mathrm{O} \rightarrow \mathrm{O}_{2}(\mathrm{~g})+4 \mathrm{H}^{+}(\mathrm{aq})+4 \mathrm{e}^{-}
$$

Reduction (at the cathode):

$$
4 \mathrm{H}_{2} \mathrm{O}+4 \mathrm{e}^{-} \rightarrow 2 \mathrm{H}_{2}(\mathrm{~g})+4 \mathrm{OH}^{-}(\mathrm{aq})
$$

Water electrolysis produces an acidic medium at the anode and an alkaline medium at the cathode. ${ }^{16}$ The ionic migration of electrolysis products has relevance on the chemistry of the solid matrix. ${ }^{19}$ The protons generated at the anode migrate towards the cathode and the hydroxide ions produced at the cathode migrate towards the anode. The progress of these acidic and alkaline fronts plays an important role on the transport and the transformations processes that affect the contaminants' migration and removal during the EKR treatment. A schematic electrochemical remediation system is presented in Figure 2.

According to Acar et al., protons are the predominant current carrier in electrochemical systems. The ionic mobility of protons under electrical field is about two times the hydroxide ion mobility. ${ }^{24}$ In unenhanced electrokinetic remediation, the acid and the alkaline fronts meet at approximately $2 / 3$ of the normalized distance from the anode, and produce a zone with a low electrical-conductivity that hinders the movement of contaminants. Therefore, it is widely accepted that, in order to success with the selective 
removal of contaminants, the application of EKR requires some enhancement to control either the protons or the hydroxide ions fronts, or both. ${ }^{25-30}$ Enhancement techniques are

typically based on the addition of reagent, ${ }^{29-31}$ the use of semipermeable membranes ${ }^{32}$ or the combination of EKR with other remediation techniques ${ }^{33}$.

For example, an acid-enhanced EKR system has the electrode compartments separated from the central compartment holding the solid matrix with passive membranes. The separators prevent from mixing of soil and electrolytes solutions. The alkaline front generated at the cathode is neutralized by means of the addition of acid, as, for example, acetic, citric or nitric acid. ${ }^{30}$ Thus, the dissolution of the heavy-metal containing minerals is promoted.

The enhancement technique based on the use of semipermeable membranes, the basic of Electrodialytic Remediation, is presented in the follow section.

\section{Fundamentals of Electrodialytic Remediation}

EDR was proposed at the Technical University of Denmark as an optimization of EKR (PCT/DK95/00209). The use of ion-exchange membranes in the process aims to: ${ }^{34-36}$

1) Reduce the amount of energy "wasted" on the transport of highly mobile ions between electrodes different than the target contaminant, such as $\mathrm{H}^{+}$or $\mathrm{OH}^{-}$;

2) Prevent the reentering of contaminants from the electrolyte solutions into solid matrix as a consequence of changes of the ion charges, for example due to the formation of complexes compounds.

A schematic diagram of the experimental lab-scale setup for the EDR cell is presented in Figure 3. In the three-compartment cell, the solid matrix is placed in the central compartment, which is separated from the cathode compartment by a cation-exchange membrane (CEM) that allows only the transport of cations, and from the anode 
compartment by an anion-exchange membrane (AEM) that allows only the entering of anions. The ion exchange membranes (IEMs) are a key in electrodialysis remediation, and their behavior is based on the concept of permselectivity which was first studied by Donnan. ${ }^{37}$ The electric potential at the membrane-solution surface, known as Donnan potential, causes the exclusion of co-ions from the membrane matrix and it can be used as a measure of the permselectivity. ${ }^{36,38,39}$

A CEM allows the passage of cations and hinders the passage of anions, while the behavior of AEM does the opposite. That is, the membrane is charged with the same sign as co-ions. Therefore, the co-ions are excluded from the membrane phase and the counter-ions can pass through the membrane. Regarding to the types of IEMs, according to the charge and distribution of fixed ionic groups, it could be distinguished between monopolar (both CEMs and AEMs) and bipolar membranes (which has one exposed surface acting as a CEM and the other exposed surface as an AEM). For EDR, the monopolar membranes are the most widely used. ${ }^{40-43}$ The IEM membranes prevent the high mobile protons and hydroxide ions to enter the central compartment promoting, therefore, more charge to be carried by the target contaminants in the matrix.

Similar to EKR, the transport phenomena occurring during EDR are: diffusion, electromigration, electroosmosis and electrophoresis. Hypothetically, a complete remediation of a solid matrix, taking into account that ions from the solid matrix are transported towards the electrode compartments but the ions from the electrode compartments are not entering the solid, would cause a solid volume without ions. This situation produces "water splitting", i.e., the dissociation of water molecules in the central compartment producing $\mathrm{H}^{+}$and $\mathrm{OH}^{-}$to carry the electric current.

Despite the AEM placed between the soil and the anode compartment hinders the transport of cations, the acidification of the central compartment has been observed 
during EDR treatments. ${ }^{44,45}$ This process is associated with the permselectivity of the membranes and with the water splitting due to a decrease of the conductivity in the regions near the surface of the membrane. Although theoretically the current cannot be higher than the limiting current, overlimiting current densities has been obtained experimentally. ${ }^{46,47}$ As a consequence of operating at those conditions, the dissociation of water causes $\mathrm{pH}$ changes around the membrane. This situation is not desirable; not only because of the deterioration of membrane but also due to the reduction of the current efficiency. The optimum situation for EDR efficiency is the application of an electric current that causes the limiting current only exceeds at the AEM. Thus, water dissociation occurs at AEM causing the entering of protons through the solid towards the cathode while no production of $\mathrm{OH}^{-}$occurs at the CEM. ${ }^{45}$ This situation has been concluded to be the most common in EDR applications. In this respect, Krol et al. have studied that the change in $\mathrm{pH}$ was evident in AEM being almost negligible for CEM. ${ }^{47}$ Some studies have related the water splitting with a thin layer at the surface of AEM caused by the protonation of groups such as tertiary amines present in the membrane. ${ }^{44,46}$ De Lara et al. studied the transport of ions across IEMs under working conditions in EDR. A small fraction of $\mathrm{H}^{+}$passing from the anode into the solid was detected even when the current was zero. Also, it was observed that the CEM acts ideally avoiding the entering of $\mathrm{OH}^{-}$present in the cathodic electrode to the solid. This phenomenon is also associated with the acidification of solid matrix during EDR experiments. $^{48}$

\section{Overview of the current status of EKR and ED: Applications.}

Electrokinetic remediation has been widely used to treat soils polluted with inorganic species and organic compounds. The inorganic pollutants can be divided into cationic toxic metals (e.g., lead and cadmium), anionic metals (e.g. arsenic and chromium) and 
radionuclides (e.g. strontium and uranium). As mentioned before, the electromigration is the most relevant transport process, but it directly depends on the specific pollutant type and solid properties. The movement of metals in soil as a consequence of applying an electric field was first reported by Segall et al. in $1980 .{ }^{49}$ Although their aim was to dewater a dredged material disposal site, conclusions from this work were an inspiration for the development of electrochemical remediation applied to soils. ${ }^{50,51}$ The early laboratory research on EKR pursued to study the fundamentals of the technique. ${ }^{22,25,52,53}$ Those works were mainly carried out using spiked kaolinite, as a first step toward the development of the technique for real soils. However, the limited variety of sorption sites for contaminants together with other shortcoming makes not possible to extrapolate the results obtained with spiked soils to industrially and aged polluted soils. ${ }^{54-56}$ Regarding large-scale EKR, an early work dealing with this subject was published by Acar and Alshawabkeh. ${ }^{57}$ The authors studied the transport of lead through a spiked soil under electric field at pilot scale without applying any enhancement method. From results, it was concluded that lead was transported toward the soil zone close to the cathode compartment where the metal precipitates as hydroxide. Although the energetic cost obtained was too high for the technique, the authors claimed that the use of enhancement techniques involved a decrease in the power consumption.

The first field-scale application of electrochemical remediation for soils was pioneer commercially by Reinout Lageman, Wiebe Pool and Geert Seffinga of Geokinetics during late 1980s. ${ }^{17}$ They patented the used of circulating electrolytes and ion permeable wells to hold the anolyte and catholyte. ${ }^{58}$ The developed technology, applied to some field soils contaminated with metals such as copper, zinc, cadmium, lead and nickel, consisted of a simple configuration with vertically or horizontally installed electrodes in the solid matrix together with drilling wells around the contaminated zone. 
The technology was based on the electrokinetic transport phenomena without the addition of enhanced solutions. Simultaneously, the pollutant transport due to the movement of water through the electrical double layer was studied at MIT $^{59}$ and at Louisiana State. ${ }^{60}$ A field demonstration of electrokinetic remediation with amendments by addition of other chemicals was conducted at the Naval Air Weapons Station (California) in 2000. The developed system included the addition of citric acid to control the $\mathrm{pH}$ in the treatment area. ${ }^{61}$ The well-known remediation technology, Lasagna $^{\mathrm{TM}}$ technology, was developed to recover soils polluted with organic compounds. The process consists in the application of an electric current to transport contaminants into the "treatment zones" where the enhancing solutions are added. The process was called "Lasagna" due to its layered configuration of treatment zones between the electrodes. ${ }^{62}$ The Lasagna technology entailed many advantages that include the possibility of recycling the cathode effluent, which would favour the neutralization of the $\mathrm{pH}$ and the simplification water management; highly flexible treatment configuration and degradation methods and potential cost-effectiveness. ${ }^{63}$

Regarding EDR, patented in 1995, the majority of studies reported in literature are performed at lab scale until now. This technique was applied to polluted soils as an insitu treatment in pioneer studies. ${ }^{34,35,64,65}$ In 1994, Jensen et al. studied the influence of $\mathrm{pH}$ value on the removal of $\mathrm{Zn}$ and $\mathrm{Cu}$ from a polluted soil, observing that higher $\mathrm{pH}$ values promoted $\mathrm{Cu}$ removal. From the EDR experiments, it was also concluded that removal of $\mathrm{Ca}$ and $\mathrm{Mg}$ was hindering the removal of the target metals. These results emphasized the importance of solid composition when EDR is applied. Ottosen et al. studied the remediation of a $\mathrm{Cu}$-polluted loamy sand from a former wood preservation plant aiming at the identification of relevant parameters to the remediation process. An important influence of the $\mathrm{pH}$ value on the removal of $\mathrm{Cu}$ was observed, finding a zone 
of accumulation of metal in a soil zone where the $\mathrm{pH}$ had increased. It was also observed that, when the current was doubled, the rate of $\mathrm{Cu}$ removal increased by a factor of approximately $2 .{ }^{34}$ Along the same lines, Hansen et al. evaluated the importance of key parameters for the optimization of the process, highlighting the importance of the $\mathrm{pH}$, the current density and the addition of complexing agents. It was concluded that: 1) the $\mathrm{pH}$ value plays an important role on the mobility, speciation and sorption/desorption of toxic metals; 2) the addition of reagent, such as complexing agents, is needed in some situations in order to selectively remove contaminants from soils; and 3) keeping the current density below the limiting current density for the interface CEM-soil to avoid "water splitting" is crucial. ${ }^{35,64}$

Ribeiro et al. applied EDR to treated timber waste containing $\mathrm{Cu}, \mathrm{Cr}$ and As using oxalic acid as assisting agent. The removal of $\mathrm{Cu}, \mathrm{Cr}$ and $\mathrm{As}$ was: 93\%, 95\% and 99\%, respectively. That study was pioneer in the application of EDR to solid matrix different than polluted soils. ${ }^{66}$ Hansen et al. studied the influence of pretreating the solid matrix, copper mine tailing, on the efficiency of EDR. The study concluded that the acidification of the mine tailing with sulfuric acid entailed speeding up the remediation process. By comparing sulfuric and citric acids for the same solid matrix, the authors concluded that the energy consumption at field scale would be lowest adding the organic acid, explained with the formation of the stable complex: $\mathrm{Cu}\left(\mathrm{C}_{6} \mathrm{H}_{7} \mathrm{O}_{7}\right)^{+}$which together with acidic conditions promotes $\mathrm{Cu}$ dissolution minerals in the solid matrix. ${ }^{67,68}$ In 2005 , a pioneer study evaluated the feasibility of the electrodialytic remediation method at a pilot-scale containing up to $2 \mathrm{~m}^{3}$ of solid matrix. This research was not only focused on the scaling-up of the technique but also on the optimization of experimental conditions. In this study, Pedersen et al. evaluated the removal of $\mathrm{Cr}$, $\mathrm{As}$ and $\mathrm{Cu}$ from 
treated wood obtained promising results: arsenic was almost completely removed from the solid matrix, and the concentration of $\mathrm{Cr}$ and $\mathrm{Cu}$ was drastically reduced. ${ }^{69}$

In spite of the promising results obtained in previously discussed research works, several factors, such as risk of exposure of adsorbed contaminants through ground water, high costs, long treatments times, difficult soil conditions, and the need for acidification to induce contaminant desorption, have limited the field implementation of EDR for some specific cases. In order to overcome these limitations, the application of electrodialytic method to suspended solid, as an on-site process, was developed for fine grained materials, such as: fly ashes ${ }^{70}$, harbor sediments ${ }^{71}$ and polluted soils ${ }^{72}$.

The typical cell for the application of electrodialytic technique to solids in suspension is shown in Figure 4. The main difference from the experimental setup for treating a stationary matrix (Figure 3) is found in the central compartment. As can be observed, it consists of a stirrer to maintain the matrix suspended instead of the stationary solid matrix. Ottosen et al. compared the two options for application of EDR previously described: 1) to remediate a wet matrix (in-situ or on-site) and 2) to remediate a solid in suspension (on-site). With this aim, experiments were carried out with soils polluted with $\mathrm{Cu}$ and $\mathrm{Pb}$. They observed a larger toxic metal mobilization in suspended soils due to faster acidification. Those results were congruent with a more efficient effect of the "water splitting" at the AEM for stirred soils, as the stirring reduced the gradients of potential nearby the membrane region. Additionally, transient and nonlinear changes occurring under the application of an electric current are overcome by the mixing for the stirred system. Nevertheless, it should be highlighted that the best option (between EDR applied to stationary soil or to stirred suspension of soil) depends on the specific case studied. In cases in which fast remediation is required, the more suitable option is the on-site treatment. On the other hand, for cases in which the fast remediation is not 
required, the electrode units could be placed directly in soils becoming the best option for economic reasons. ${ }^{72,73}$

Regarding to the key parameters for EDR applied to suspended solids, the $\mathrm{pH}$ is the one which influence more the remediation results. The acidification of suspended soils is due to: 1) the exchange of $\mathrm{H}^{+}$from the catholyte with cations from the solid suspension caused by the inter-diffusion over the CEM and 2) the water splitting at AEM. Jensen et al. studied the influence of current density and the liquid to solid ratio (L/S) on the water splitting concluding that higher values of these parameters could cause that the limiting current at the CEM would be exceeded. That would involve water splitting at CEM and, consequently, $\mathrm{OH}^{-}$entering the solid and hindering the remediation processes. ${ }^{74}$ In this line, Sun et al. compared the removal of $\mathrm{Cu}$ and As from different soil fractions using different liquid to solid ratios and current intensities. They concluded that the removal efficiency for both metals in soil fines is higher than in the original soil. In that work, it was also highlighted the importance of optimizing the L/S ratio and the remediation current for $\mathrm{ED}$, finding that $\mathrm{L} / \mathrm{S}>7$ leads to very fast acidification processes hindering the transport of $\mathrm{Cu}$ and $\mathrm{As}^{75}$.

Recently, a new electrodialytic setup, schematically presented at Figure 5, has been developed and patented at DTU (PCT/EP2014/068956). The new design for EDR consist of two compartments separated by a cation exchange membrane. The polluted material in suspension is directly placed in the stirred anode compartment.

The 2-Cell EDR design has been proven to reduce the acidification time since the supply of protons from electrolysis takes place directly in the suspended solid compartment. ${ }^{76}$ Several studies has applied EDR to different solid matrices using twocompartment cell. ${ }^{42,77-82}$ Regarding EDR applications, it has been widely applied to different matrices as can be concluded from numerous research works previously 
discussed. Table 3 summarizes relevant information about important studies dealing with EDR applied to different matrices. 
Table 1. Application of EDR to different solid matrices. (*options for application: a) to treat the solid as stationary or b) to treat the solid as suspension)

\begin{tabular}{|c|c|c|c|c|c|}
\hline Description & Cell * & Solid matrix & Electrolytes & Target species & Ref. \\
\hline Remediation of heavy metal polluted soil & $3-\mathrm{C}^{\mathrm{a}}$ & Polluted soil & $\begin{array}{l}0.01 \mathrm{M} \mathrm{NaNO}_{3}(\mathrm{pH} \text { adjusted } \\
\left.\text { to } 3 \text { using } \mathrm{HNO}_{3}\right)\end{array}$ & $\begin{array}{l}\text { Toxic metals }(\mathrm{Cu}, \\
\mathrm{Cr}, \mathrm{Hg}, \mathrm{Pb} \text { and } \mathrm{Zn})\end{array}$ & Hansen et al (1997) ${ }^{35}$ \\
\hline $\begin{array}{l}\text { Remediation of soil polluted with } \mathrm{Cu} \text { from Wood } \\
\text { Preservation Industry }\end{array}$ & $3-\mathrm{C}^{\mathrm{a}}$ & $\begin{array}{l}\text { Polluted soil } \\
\text { Enhancement: } \\
\text { addition to the soil. }\end{array}$ & $\begin{array}{l}0.01 \mathrm{M} \mathrm{NaNO}_{3}(\mathrm{pH} \text { adjusted } \\
\left.\text { to } 3 \text { using } \mathrm{HNO}_{3}\right)\end{array}$ & $\begin{array}{l}\text { Toxic metals }(\mathrm{Cu}, \\
\text { As) }\end{array}$ & Ottosen et al. (1997) ${ }^{34}$ \\
\hline Removal of $\mathrm{Cu}, \mathrm{Cr}$ and As from Treated Timber Waste & $3-\mathrm{C}^{\mathrm{a}}$ & Treated timber waste & $\begin{array}{l}0.01 \mathrm{M} \mathrm{NaNO}_{3}(\mathrm{pH} \text { adjusted } \\
\left.\text { to } 2-3 \text { using } \mathrm{HNO}_{3}\right)\end{array}$ & $\begin{array}{l}\text { Toxic metals }(\mathrm{Cu}, \\
\mathrm{Cr}, \mathrm{As})\end{array}$ & $\begin{array}{l}\text { Ribeiro et al. (2000) } \\
\text { Velizarova el al. (2002) } \\
\text { (33 }\end{array}$ \\
\hline $\begin{array}{l}\text { Removal of } \mathrm{Cu} \text { from a real soil sampled at a wood } \\
\text { preservation site in presence of different types of } \\
\text { construction refuse in the soil on ED. }\end{array}$ & $3-C^{a}$ & $\begin{array}{l}\text { Soil from a wood preservation } \\
\text { site (Some experiments: adding } \\
\text { a construction refuse placed in } \\
\text { the soil). }\end{array}$ & $\begin{array}{l}0.01 \mathrm{M} \mathrm{NaNO}_{3}(\mathrm{pH} \text { adjusted } \\
\text { to } 2 \text { using } \mathrm{HNO})\end{array}$ & Toxic metals $(\mathrm{Cu})$ & Ottosen et al. (2002) ${ }^{84}$ \\
\hline Removal of toxic metals from different fly ashes & $3-C^{a}$ & $\begin{array}{l}\text { Municipal Solid } \\
\text { incinerator (MSWI) fly ashes } \\
\text { and wood combustion fly ashes. } \\
\text { Enhancement: addition of an } \\
\text { ammonium citrate and NH3 } \\
\text { mixture to the ash. }\end{array}$ & $\begin{array}{l}0.01 \mathrm{M} \mathrm{NaNO}_{3}(\mathrm{pH}<2 \text { using } \\
\left.\mathrm{HNO}_{3}\right) \\
0.25-0.5 \quad \mathrm{M} \quad \text { ammonium } \\
\text { citrate } / 1.25-2.5 \% \mathrm{NH}_{3}\end{array}$ & $\begin{array}{l}\text { Toxic metals }(\mathrm{Cd}, \\
\mathrm{Pb}, \mathrm{Zn} \text { and } \mathrm{Cu})\end{array}$ & Pedersen et al. (2003) ${ }^{70}$ \\
\hline Removal of toxic metals from straw combustion fly ash & $3-\mathrm{C}^{\mathrm{a}}$ & Straw combustion fly ash & $\begin{array}{l}0.01 \mathrm{M} \mathrm{NaNO}_{3}(\mathrm{pH} \text { adjusted } \\
\left.\text { to } 2 \text { using } \mathrm{HNO}_{3}\right)\end{array}$ & Toxic metals $(\mathrm{Cd})$ & Hansen et al. (2004) ${ }^{85}$ \\
\hline Removal of toxic metals from wastewater sludge & $3-\mathrm{C}^{\mathrm{a}}$ & Wastewater sludge & $\begin{array}{l}0.01 \mathrm{M} \mathrm{NaNO}_{3}(\mathrm{pH} \text { below } 2 \\
\left.\text { using } \mathrm{HNO}_{3}\right)\end{array}$ & Toxic metals $(\mathrm{Cd})$ & Jakobsen et al (2004) ${ }^{86}$ \\
\hline Remediation of Copper mine tailings & $3-\mathrm{C}^{\mathrm{a}}$ & $\begin{array}{l}\text { Mine tailing } \\
\text { Enhancement: addition of citric } \\
\text { or sulphuric acid to the solid. }\end{array}$ & $\begin{array}{l}\text { Distilled water (pH below } 4 \\
\text { using } \mathrm{H}_{2} \mathrm{SO}_{4} \text { at the catholyte) }\end{array}$ & Toxic metals $(\mathrm{Cu})$ & $\begin{array}{l}\text { Rojo and Hansen (2005) } \\
\text { Hansen et al (2005) }\end{array}$ \\
\hline Remediation of habor sediments & $3-\mathrm{C}^{\mathrm{b}}$ & Harbor sediments & $\begin{array}{l}0.01 \mathrm{M} \mathrm{NaNO}_{3}(\mathrm{pH} \text { below } 2 \\
\left.\text { using } \mathrm{HNO}_{3}\right)\end{array}$ & $\begin{array}{l}\text { Toxic metals }(\mathrm{Cu} \\
\mathrm{Zn}, \mathrm{Pb} \text { and } \mathrm{Cd})\end{array}$ & Nystroem et al. (2005) ${ }^{44}$ \\
\hline Remediation of treated waste wood in pilot scale & $3-\mathrm{C}^{\mathrm{a}}$ & $\begin{array}{l}\text { Treated waste wood } \\
\text { Enhancement: addition of } 5 \% \\
\text { oxalic acid solution or a mixture } \\
\text { of water/Na benzoate. } \\
\text { Pretreatment: Soaking step: } 5 \% \\
\text { oxalic acid, } 0.5 \mathrm{M} \mathrm{H}_{3} \mathrm{PO}_{4} \\
\end{array}$ & $\mathrm{NaNO}_{3}$ or oxalic acid & $\begin{array}{l}\text { Toxic metals }(\mathrm{Cu}, \\
\mathrm{Cr} \text { and } \mathrm{As})\end{array}$ & $\begin{array}{l}\text { Pedersen et al. (2005) }{ }^{69} \\
\quad \text { Ribeiro et al. (2007) }\end{array}$ \\
\hline Remediation of MSWI fly ash & $3-\mathrm{C}^{\mathrm{b}}$ & MSWI fly ash & $\begin{array}{l}0.01 \mathrm{M} \mathrm{NaNO}_{3}(\mathrm{pH} \text { below } 2 \\
\text { using } \mathrm{HNO}_{3} \text { at catholyte) }\end{array}$ & $\begin{array}{l}\text { Toxic metals }(\mathrm{Cu} \\
\mathrm{Pb}) \text { and } \mathrm{Cl}\end{array}$ & Ottosen et al. (2006) ${ }^{88}$ \\
\hline $\begin{array}{l}\text { Remediation of polluted soil (spiked kaolinite spiked soil } \\
\text { and industrial polluted soil) }\end{array}$ & $3-\mathrm{C}^{\mathrm{a}}$ & Polluted soil & $\begin{array}{l}0.01 \mathrm{M} \mathrm{NaNO}_{3}(\mathrm{pH} \text { below } 2 \\
\text { using } \mathrm{HNO}_{3} \text { at catholyte) }\end{array}$ & Toxic metals $(\mathrm{Cu})$ & Ottosen et al. (2006) ${ }^{54}$ \\
\hline Remediation of polluted soil & $3-\mathrm{C}^{\mathrm{b}}$ & Soil fines & $0.01 \mathrm{M} \mathrm{NaNO}_{3}(\mathrm{pH}$ between & Toxic metals $(\mathrm{Pb})$ & Jensen et al. (2006) ${ }^{89}$ \\
\hline
\end{tabular}




\begin{tabular}{|c|c|c|c|c|c|}
\hline Description & Cell * & Solid matrix & Electrolytes & Target species & Ref. \\
\hline & & & $\begin{array}{l}1-2 \text { using } \mathrm{HNO}_{3} \text { at catholyte } \\
\text { and } \mathrm{NaOH} \text { at anolyte) }\end{array}$ & & \\
\hline $\begin{array}{l}\text { Recovery of toxic metals from sewage sludge ash from } \\
\text { fluidized bed combustion }\end{array}$ & $3-\mathrm{C}^{\mathrm{b}}$ & $\begin{array}{l}\text { Sewage sludge ash from } \\
\text { fluidized bed combustion }\end{array}$ & $\begin{array}{l}0.01 \mathrm{M} \mathrm{NaNO}_{3}(\mathrm{pH} \text { below } 2 \\
\text { using } \mathrm{HNO}_{3} \text { at catholyte) }\end{array}$ & $\begin{array}{l}\text { Toxic metals }(\mathrm{Cd}, \\
\mathrm{Cr}, \mathrm{Cu}, \mathrm{Pb}, \mathrm{Ni} \text { and } \\
\mathrm{Zn})\end{array}$ & Pazos et al. (2010) ${ }^{90}$ \\
\hline $\begin{array}{l}\text { Removal of Cd from biomass combustion fly ash } \\
\text { suspensions }\end{array}$ & $3-\mathrm{C}^{\mathrm{b}}$ & Biomass combustion fly ash & $\begin{array}{l}0.01 \mathrm{M} \mathrm{NaNO}_{3}(\mathrm{pH} \text { below } 2 \\
\text { using } \mathrm{HNO}_{3} \text { at catholyte) }\end{array}$ & Toxic metals $(\mathrm{Cd})$ & Kirkelund et al. (2013) ${ }^{91}$ \\
\hline $\begin{array}{l}\text { Separation of Phosphorus and toxic metals from sewage } \\
\text { sludge ash }\end{array}$ & $\begin{array}{l}3-\mathrm{C} \\
(1,2) \mathrm{b} \\
2-\mathrm{C}^{(3) b}\end{array}$ & $\begin{array}{l}\text { Sewage sludge ash Dissolution } \\
\text { of } \mathrm{H}_{2} \mathrm{SO}_{4}\end{array}$ & $\begin{array}{l}0.01 \mathrm{M} \mathrm{NaNO}_{3}(\mathrm{pH} \text { below } 2 \\
\text { using } \mathrm{HNO}_{3} \text { at catholyte) }\end{array}$ & $\begin{array}{l}\mathrm{P} \text { and toxic metals } \\
\text { (such as: } \mathrm{Cu}, \mathrm{Zn} \text {, } \\
\mathrm{Ni}, \mathrm{Pb}, \mathrm{Al}, \mathrm{Fe}, \mathrm{Cd} \text {, } \\
\mathrm{Cr} \text { ) }\end{array}$ & $\begin{array}{l}\text { Ottosen et al. (2014) }{ }^{92(1)} \\
\text { Guedes et al. (2014) } 93(2) \\
\text { Ottosen et al. (2016) }\end{array}$ \\
\hline $\begin{array}{l}\text { Remediation of polychlorinated biphenyls (PCB) } \\
\text { contaminated soil with iron nanoparticles and surfactants }\end{array}$ & $2-\mathrm{C}^{\mathrm{b}}$ & $\begin{array}{l}\text { Soil with organic pollutants } \\
\text { Enhancements: Use of saponin } \\
\text { and Tween } 80 \text { as surfactant. }\end{array}$ & $\begin{array}{l}0.01 \mathrm{M} \mathrm{NaCl}(\mathrm{pH} \text { control } \\
\text { with } \mathrm{HCl})\end{array}$ & $\begin{array}{l}\text { Organic } \\
\text { contaminants } \\
\text { (polychlorinated } \\
\text { biphenyls) }\end{array}$ & Gomes et al. (2014) ${ }^{41}$ \\
\hline $\begin{array}{l}\text { Simultaneous removal of organic pollutants and toxic } \\
\text { metals from sediments }\end{array}$ & $3-\mathrm{C}^{\mathrm{b}}$ & Sediments & $\begin{array}{l}0.01 \mathrm{M} \mathrm{NaNO}_{3}(\mathrm{pH} \text { below } 2 \\
\text { using } \mathrm{HNO}_{3} \text { at catholyte) }\end{array}$ & $\begin{array}{l}\text { Organic } \\
\text { contaminants } \\
(\mathrm{PAH}, \mathrm{PCD}, \mathrm{TBT}) \\
\text { and toxic metals } \\
(\mathrm{Cu}, \mathrm{Pb} \text { and } \mathrm{Zn})\end{array}$ & Pedersen et al. (2017) ${ }^{94,95}$ \\
\hline
\end{tabular}




\section{A new challenge for EDR: Li-Ion batteries recycling}

From the previous discussion, it can be concluded that EDR has a great potential in the recovery of toxic metals from solid matrices (for example: soil, wood chips, fly ashes, sediments and mine tailing). This section addresses the potential application of EDR to residues from secondary batteries such as lithium ion batteries (henceforth LIBs), as well as it provides new insights into a problem of public concern. To that end, it is discussed the current situation of LIB recycling processes and the most relevant characteristic of the solid waste for the application of EDR.

\section{An overview of current situation of LIBs recycling processes}

Lithium-ion batteries are the main energy storage device used in modern electronics, widely used nowadays in most portable electronic devices. Other applications that are increasing the demand of LIB are the hybrid and electric vehicles and the storage for energy from renewable sources and self-production. The wide range of applications of this kind of batteries is motivated by their characteristics: high energy density, long cycle lives, high roundtrip efficiency, wide range of operating temperature, high reliability, safety, chemistry with eco-friendly materials, fast recharge and low selfdischarge rate..$^{96,97}$

The use of LIBs in these sectors promotes the development of technologies with lower carbon emissions. For example, the US Energy Information has predicted that sales of electric vehicles will reach 6.9 million units ${ }^{98}$ by 2035 . The demand for LIBs in these emerging sectors entails an increase in the attention paid to the recycling of spent batteries. $^{99-101}$ It is estimated that the percentage of lithium used to manufacture batteries will increase to $66 \%$ of the current global production by 2025 . Regarding 
lithium recovery, a UNEP status report states that less than $1 \%$ of lithium is being recycled. ${ }^{15}$ Furthermore, currently $~ 95 \%$ of LIBs are landfilled. ${ }^{102}$

Despite lithium itself is considered an environmentally-friendly material, the disposal of waste from this kind of batteries entails a risk for the environment as some of the components of the cells have high degree of toxicity. According to the European Union, some of the elements used in LIBs, such as cobalt and natural graphite, have a high economic importance and a high supply-risk, being classified as "Critical Raw Materials". ${ }^{103}$ Indeed, cobalt is considered a bottleneck in the LIB industry, which can only be addressed by battery recovery and recycling. Other relevant elements for the Liion battery sector are $\mathrm{Al}, \mathrm{Fe}, \mathrm{Ti}, \mathrm{P}, \mathrm{Mn}, \mathrm{Ni}$ and $\mathrm{Cu}$. Current trends will also place lithium in the list of critical materials by $2030 .{ }^{96}$ Furthermore, lithium resources, mainly extracted from brine lakes and salt pans, are located in a very limited number of regions, namely in Argentina, Chile, Bolivia, China, USA, Canada, Russia, Congo and Serbia.

It is clear that battery recycling processes are necessary to reach sustainable ways to reduce the negative impact on the environment and the reuse of natural resources, as well as to decrease the dependence of international suppliers. ${ }^{104}$

\section{Chemical composition of LIBs waste}

LIBs consist of a couple of electrodes usually contained in a stainless-steel shell or in a pouch case. During the operation of a LIB (discharge) lithium ion migrate from anode to cathode, producing electric current.

The most frequent anodic material is graphite supported on a copper foil that acts as a current collector. The current gravimetric capacity (amount of lithium that can be stored per mass of anodic material) of graphite anodes is around $372 \mathrm{mAh} \mathrm{g}^{-1}$. New anode materials, such as lithium titanate $\left(\mathrm{LiTi}_{5} \mathrm{O}_{12}\right)$, carbon nanotubes or $\mathrm{Al}, \mathrm{Sn}$ and $\mathrm{Si}$ 
compounds, are being studied to be used as alternative anodes. ${ }^{105-107}$ The aforementioned materials would increase the value of the waste of LIBs involving a significant growth of the concern about recycling processes.

The cathode is generally built from transition metals oxides. The cathode, supported on an aluminum foil, is composed of: $\sim 85 \%$ metal oxide, $\sim 10 \%$ polyvinylidene fluoride and $\sim 5 \%$ carbon. ${ }^{101,108}$ The most commonly used oxides in commercial batteries are: lithium cobalt oxide ( $\mathrm{LCO}$ or $\left.\mathrm{LiCoO}_{2}\right)$, lithium manganese oxide ( $\mathrm{LMO}$ or $\left.\mathrm{LiMn}_{2} \mathrm{O}_{4}\right)$, lithium nickel manganese cobalt oxide $\left(\mathrm{NMC}\right.$ or $\left.\mathrm{LiNiMnCoO}_{2}\right)$ and lithium nickel cobalt aluminum oxide ( $\mathrm{NCA}$ or $\left.\mathrm{LiNiCoAlO}_{2}\right)$. The LCO batteries has the higher recycling value among the different batteries chemistries due to the higher amount of Co and Li. ${ }^{104}$

The separator, placed between the anode and the cathode, is usually made of polypropylene or microporous polyethylene. The cells also contain as electrolyte a lithium salt $\left(\mathrm{LiPF}_{6}, \mathrm{LiBF}_{4}\right.$ or $\left.\mathrm{LiClO}_{4}\right)$ in a non-aqueous solvent as, e.g., a mixture of ethylene glycol carbonate, propylene carbonate and dimethyl carbonate. ${ }^{100,109}$ The electrolyte role is allowing the movement of lithium ions during the cycling process.

The bulk compositions of LIB are shown in Table 4.

Table 2. Average composition of LIBs from literature.

\begin{tabular}{|c|c|c|c|}
\hline & \multicolumn{3}{|c|}{ Concentration $(\mathrm{wt} \%)$} \\
\hline & Wang et al. (2016) ${ }^{110}$ & Jha et al. $(2013)^{111}$ & Dorella and Mansur (2017) \\
\hline \multicolumn{4}{|c|}{ Metals } \\
\hline Aluminum & 5.20 & 4.30 & 8.02 \\
\hline Cobalt & 17.30 & 23.67 & 29.49 \\
\hline Copper & 7.30 & 22.13 & 16.48 \\
\hline Iron / Steel & 16.50 & $*$ & $*$ \\
\hline Nickel & 1.20 & 0.26 & 0.02 \\
\hline Lithium & 2.00 & 2.87 & 3.14 \\
\hline \multicolumn{4}{|c|}{ Others } \\
\hline Binders & 2.40 & $*$ & $*$ \\
\hline Carbon (no & 6.00 & $*$ & $*$ \\
\hline
\end{tabular}




\begin{tabular}{lccc}
\hline graphite) & & & $*$ \\
\hline $\begin{array}{l}\text { Electrolyte }+ \\
\text { Organic solution }\end{array}$ & 14.00 & $*$ & $*$ \\
\hline Graphite & 23.10 & $*$ & $*$ \\
\hline Plastics & 4.80 & $*$ & Balance \\
\hline Other & Balance & Balance & \\
\hline
\end{tabular}

The composition and the mass of the different cells vary depending on the type of battery chemistry and the manufacturers. ${ }^{113}$ Approximately $25-30 \%$ of the total mass of the battery corresponds to the cathode, where most of the toxic metals are found. The anode represents between $15-30 \%$ of the total mass of the battery. ${ }^{104}$

\section{Current LIBs recycling solutions}

Swain presented a comprehensive review ${ }^{15}$ on techniques for recovery and recycling LIBs, and classified the processes into: pyro-metallurgical, hydro-metallurgical, biohydrometallurgical and combined techniques. The pyro-metallurgical and hydrometallurgical processes are the most used. Pyro-metallurgy is based on the application of thermal treatments to induce chemical changes in the residue while hydrometallurgical processes take advantage of the chemical properties of metals in aqueous solutions for the recovery of the different components. ${ }^{15}$ Currently, bio-metallurgical processes, based on the use of microorganisms (bacteria and fungi), are gaining importance with respect of hydro-metallurgical due to their higher efficiency, lower cost and fewer resources requirements. ${ }^{104}$ In these processes, the formation of metabolic products, such as organic and inorganic acids, directly influences on the recovery efficiency of metals contained in the waste. ${ }^{114}$ Some of the most important companies in the recycling of rechargeable batteries (Umicore, Toxco, Inmeco and Recupyl) develop their own processes based on pyrometallurgical, hydrometallurgical and combined techniques. ${ }^{15,109,115}$ 
Several studies deal with the extraction of metals (mainly Li and Co) from disposed LIBs, use different extractant agents, such as inorganic acids $\left(\mathrm{H}_{2} \mathrm{SO}_{4}{ }^{99,111,116}, \mathrm{HCl}\right.$ ${ }^{117,118}, \mathrm{HNO}_{3}{ }^{117,119}$ or $\mathrm{H}_{3} \mathrm{PO}_{4}{ }^{120,121}$ ) and, as alternative with a lower negative impact on the environment, organic acids ${ }^{117}$ (succinic acid ${ }^{122}$, maleic acid ${ }^{123,124}$, citric acid ${ }^{123,125}$, EDTA $^{126}$, ascorbic acid ${ }^{127}$, tartaric acid ${ }^{117}$ or acetic acid ${ }^{123,128}$ ).

The addition of reductants in acid leaching processes is widely accepted since $\mathrm{Co}^{3+}$ in LCO needs to be converted to $\mathrm{Co}^{2+} . \mathrm{H}_{2} \mathrm{O}_{2}$ is used as reductant because it do not add new ions into the solution. ${ }^{111,124}$ It should be noted that the absence of reductant could be interesting to selective recovery Li. The dissolution of LCO in $\mathrm{H}_{2} \mathrm{SO}_{4}$ has been widely demonstrated to be difficult due to the strong bond between cobalt and oxygen. For this reason, a reductant, as it was aforementioned, such as hydrogen peroxide is added to promote the dissolution. ${ }^{116}$ The reactions taking place are:

$$
\begin{aligned}
& 4 \mathrm{LiCoO}_{2 \text { (s) }}+6 \mathrm{H}_{2} \mathrm{SO}_{4(\text { (aq.) }} \rightarrow 2 \mathrm{Li}_{2} \mathrm{SO}_{4(\text { aq. }}+4 \mathrm{CoSO}_{4(\text { aq.) }}+6 \mathrm{H}_{2} \mathrm{O}_{\text {(aq.) }}+\mathrm{O}_{2 \text { (g) }} \\
& 2 \mathrm{LiCoO}_{2 \text { (s) }}+3 \mathrm{H}_{2} \mathrm{SO}_{4 \text { (aq.) }}+\mathrm{H}_{2} \mathrm{O}_{2 \text { (aq.) }} \rightarrow \mathrm{Li}_{2} \mathrm{SO}_{4 \text { (aq.) }}+2 \mathrm{CoSO}_{4 \text { (aq.) }}+4 \mathrm{H}_{2} \mathrm{O}_{\text {(aq.) }}+\mathrm{O}_{2 \text { (g) }}
\end{aligned}
$$

Jha et al. studied the influence of several parameters in the hydrometallurgical process for the recovery of $\mathrm{Li}$ and $\mathrm{Co}$ from LIBs of mobile phone using sulfuric acid as lixiviate. Their results showed an increase in the percentage of leaching of Co and $\mathrm{Li}$ with higher concentration of acid (in presence of $\mathrm{H}_{2} \mathrm{O}_{2}$ ), temperature and time. On the industrial applications, it should be highlighted that $\mathrm{H}_{2} \mathrm{SO}_{4}$ is the only used agent. The addition of other inorganic acid, such as $\mathrm{HCl}$, have limitations such as the emission of gases $\left(\mathrm{Cl}_{2}\right) .{ }^{111}$

Gao et al. analyzed the leaching efficiencies using different organic and inorganic acids, concentrations, $\mathrm{S} / \mathrm{L}$ ratios, reductant agents and temperature. According to their results, it was concluded that the use of inorganic acids allowed higher leaching efficiency than 
organic acids, as well as higher treatment capacity. This fact was associated with the higher concentration of $\mathrm{H}^{+}$. Also, the authors observed that the higher initial $\mathrm{pH}$ value of the solution was, the lower leaching speeds of $\mathrm{Li}$ and Co was obtained. Regarding to the addition of organic acids, selective separating of other important metals presented in the LIBs waste, such as $\mathrm{Al}$, is achieved. However, for organic acids, the low $\mathrm{S} / \mathrm{L}$ ratio is one of the problems for applications at field scale. For this reason, they proposed to combine the use of organic and inorganic acids to improve the recovery of metals from solid. ${ }^{117}$

\section{Proposal of a novel way for LIBs recycling.}

The application of EDR to residues from spent LIBs requires the development of a pretreatment process. First, the LIBs must be separated and sorted according to the cathode chemistry with the aim of making the process more efficient. ${ }^{110}$ With this purpose, the so-called SORBAREC system was developed. This technology identifies LIB types using X-Ray transmission. ${ }^{129}$ Before disassembling the batteries, it is important to carry out a discharge step in order to remove the excess capability. It is aiming at avoiding the risk of short-circuiting and self-ignition associated with the potential contact of anode and cathode. ${ }^{125}$ The discharge could be performed by immersing the LIBs in liquid nitrogen or in sodium chloride solution. ${ }^{125,130}$ After this, mechanical methods are applied to reduce scrap volume and to concentrate valuable metals. Sometimes, the use of thermal processes is carried out in order to effectively isolate the cathode materials obtaining scraps with a higher content of the target metals, Co and Li. ${ }^{131}$ Before applying the recovery method, it is also required in order to characterize the LIBs waste in order to optimize the design of the EDR application.

So far, most of the research related to the use of electrodialysis for the recovery of lithium focus on improving the separation processes in brines. ${ }^{132,133}$ The application of the EDR to LIBs residues could be performed according to the principles described in 
this paper. It would require the optimization of the most relevant operating parameters, such as $\mathrm{pH}$ value, selection of enhancing agent, current density, type of membrane, L/S ratio. Iizuka et al. carried out the separation of $\mathrm{Li}$ and $\mathrm{Co}$ from a solution that reproduced the content of these metals in the waste coming from Li-Ion batteries. ${ }^{126}$ In that research, promising results were obtained by making use, as an improvement agent, of EDTA.

Song and Zhao proposed a promising method of extracting lithium from lithium highsalt solution since conventional methods, such as evaporation and concentration, are time and energy consuming resulting in low recovery efficiencies. The method is based on the precipitation of $\mathrm{Li}$ to $\mathrm{Li}_{3} \mathrm{PO}_{4}$ prior separation via $\mathrm{ED}$. The experimental system consisted of an electrolytic cell with cation-exchange membranes, titanium cathode and graphite anode. By optimizing the solution $\mathrm{pH}$, about $99 \%$ of impurity metals were effectively precipitated. After the precipitation of $\mathrm{Li}$ to $\mathrm{Li}_{3} \mathrm{PO}_{4}$ by addition of sodium phosphate, the ED was applied obtaining a decreased of P/Li from 1.48 to 0.23 . ${ }^{134}$ These promising results showed that the proposed method has great potential as a recovery method of Li from spent secondary batteries. To the best of our knowledge, the literature reported regarding the application of ED to LIBs recycling is very scarce without any reference regarding ED applied to solid waste. Therefore, further research regarding the recovery not only of lithium but also of cobalt applying the electrodialysis to solid wastes is needed.

\section{Conclusions}

This review allows a new insight into potential applications of EDR. The optimization of key parameters for EDR, such as $\mathrm{pH}$ value, selection of enhancing agent, current density, type of membrane, is discussed reporting relevant results found by different 
authors. From literature, it could be concluded that, among other issues, further studies about membrane selection according to different solid matrices treated are needed.

This work also interrelated the EDR studies reported in literature and the knowledge of current recycling processes of LIBs to propose a new approach for an emerging public concern issue: the revalorization of metals from spent batteries. It has been widely demonstrated that the understanding of the metal behavior in presence of acidic solution results essential to optimize key parameters in EDR. The acidification processes taking place in EDR treatments is one of the most influential processes in the effectiveness of remediation technology. Further studies taking into account the characteristics of LIBs waste, as well as the potential use of combination of inorganic and organic acids as enhancing agents are needed to reach a successful application of EDR. For that, the issues discussed in this work, such as: the understanding of the principles of EDR applied to solid matrices and the relevance of solid characterization for the design and optimization of experimental conditions; establish the initial steps to the design and optimization of the technology.

\section{Acknowledgements}

The authors acknowledge the financial support from the "Plan Propio de Investigación de la Universidad de Málaga with Project numbers: PPIT.UMA.B1.2017/20 and PPIT.UMA.B5.2018/17 and the European project THROUGH H2020-MSCA-RISE2017-778045. The first author also acknowledge the postdoctoral contract obtained from University of Malaga. 


\section{References}

1 Bazinet L, Lamarche F, Ippersiel D. Bipolar-membrane electrodialysis: Applications of electrodialysis in the food industry. Trends Food Sci Technol 9:107-113 (1998).

2 Shaposhnik VA, Kesore K. An early history of electrodialysis with permselective membranes. J Membr Sci 136:35-39 (1997).

3 Maigrot E, Sabates J. Apparat zur Liuterung von Zuckersiften mittels Elektrizitiit. (1889).

4 Ostwald W. Elektrische eigenschaften halbdurchlässiger scheidewände. Z Für Phys Chem 6:71-82 (1890).

5 Strathmann H. Chapter 6 Electrodialysis and related processes. In: Noble RD, Stern SA (eds). Membrane Science and Technology. Elsevier, pp 213-281 (1995).

$6 \quad$ Stucki S. Process Technologies for Water Treatment. Springer US (2013). .

7 Helfferich F, Dranoff J. Ion Exchange. McGraw-Hill Book Co.: New York (1962).

8 Paidar M, Fateev V, Bouzek K. Membrane electrolysis-History, current status and perspective. Electrochimica Acta 209:737-756 (2016).

9 Huang C, Xu T, Zhang Y, Xue Y, Chen G. Application of electrodialysis to the production of organic acids: State-of-the-art and recent developments. $J$ Membr Sci 288:1-12 (2007).

10 Turek M. Electrodialytic desalination and concentration of coal-mine brine. Desalination 162:355-359 (2004).

11 Luiz A, Spencer E, McClure DD, Coster HGL, Barton GW, Kavanagh JM. Membrane selection for the desalination of bio-refinery effluents using electrodialysis. Desalination 428:1-11 (2018).

12 Chen GQ, Eschbach FII, Weeks M, Gras SL, Kentish SE. Removal of lactic acid from acid whey using electrodialysis. Sep Purif Technol 158:230-237 (2016).

13 Merkel A, Ashrafi AM, Ečer J. Bipolar membrane electrodialysis assisted pH correction of milk whey. J Membr Sci 555:185-196 (2018).

14 Lee J-H, Choi J-H. The production of ultrapure water by membrane capacitive deionization (MCDI) technology. J Membr Sci 409-410:251-256 (2012).

15 Swain B. Recovery and recycling of lithium: A review. Sep Purif Technol 172:388-403 (2017).

16 Acar YB, Alshawabkeh AN, Gale RJ. Fundamental aspects of electrokinetic remediation of soils. Waste Manag 13:513 (1993). 
17 Lageman R, Pool W, Seffinga GA. Electroreclamation, a new technique for in-situ removal of pollutants. LAND WATER 28 (1988).

18 Pamukcu Sibel, Wittle J. Kenneth. Electrokinetic removal of selected heavy metals from soil. Environ Prog 11:241-250 (1992).

19 Reddy KR, Cameselle C. Overview of Electrochemical Remediation Technologies. In: Electrochemical Remediation Technologies for Polluted Soils, Sediments and Groundwater. , pp 1-28 (2009).

20 Alshawabkeh AN. Electrokinetic soil remediation: Challenges and opportunities. Sep Sci Technol 44:2171-2187 (2009).

21 Paz-García JM, Johannesson B, Ottosen LM, Ribeiro AB, Rodríguez-Maroto JM. Modeling of electrokinetic processes by finite element integration of the NernstPlanck-Poisson system of equations. Sep Purif Technol 79:183-192 (2011).

22 Acar YB, Alshawabkeh AN. Electroosmotic removal of gasoline hydrocarbons and tce from clay. J Environ Eng U S 119:404-406 (1993).

23 Ribeiro A, Rodríguez Maroto J. Electroremediation of Heavy Metal-Contaminated Soils -Processes and Applications. In: Trace Elements in the Environment. CRC Press. Taylor \& Francis, pp 325-340 (2006).

24 Acar YB, Gale RJ, Alshawabkeh AN, Marks RE, Puppala S, Bricka M et al. Electrokinetic remediation: Basics and technology status. J Hazard Mater 40:117137 (1995).

25 Coletta TF, Bruell CJ, Ryan DK, Inyang HI. Cation-enhanced removal of lead from kaolinite by electrokinetics. J Environ Eng 123:1227-1233 (1997).

26 Garcia-Gutierrez MD, Gomez-Lahoz C, Rodriguez-Maroto JM, Vereda-Alonso C, Garcia-Herruzo F. Electrokinetic remediation of a soil contaminated by the pyritic sludge spill of Aznalcollar (SW, Spain). Electrochimica Acta 52:3372-3379 (2007).

27 Pazos M, Ricart MT, Sanromán MA, Cameselle C. Enhanced electrokinetic remediation of polluted kaolinite with an azo dye. Electrochimica Acta 52:33933398 (2007).

28 Puppala SK, Alshawabkeh AN, Acar YB, Gale RJ, Bricka M. Enhanced electrokinetic remediation of high sorption capacity soil. J Hazard Mater 55:203220 (1997).

29 Reddy KR, Chinthamreddy S. Enhanced electrokinetic remediation of heavy metals in glacial till soils using different electrolyte solutions. J Environ Eng 130:442-455 (2004).

30 Villen-Guzman M, Paz-Garcia JM, Rodriguez-Maroto JM, Gomez-Lahoz C, Garcia-Herruzo F. Acid Enhanced Electrokinetic Remediation of a Contaminated Soil using Constant Current Density: Strong vs. Weak Acid. Sep Sci Technol 49:1461-1468 (2014). 
31 Villen-Guzman M, Garcia-Rubio A, Paz-Garcia JM, Rodriguez-Maroto JM, Garcia-Herruzo F, Vereda-Alonso C et al. The use of ethylenediaminetetraacetic acid as enhancing agent for the remediation of a lead polluted soil. Electrochimica Acta 181:82-89 (2015).

32 Parés Viader R, Jensen PE, Ottosen LM. Electrodialytic remediation of municipal solid waste incineration residues using different membranes. Chemosphere 169:62-68 (2017).

33 Lageman R, Godschalk MS. Electro-bioreclamation. A combination of in situ remediation techniques proves successful at a site in Zeist, the Netherlands. Electrochimica Acta 52:3449-3453 (2007).

34 Ottosen LM, Hansen HK, Laursen S, Villumsen A. Electrodialytic remediation of soil polluted with copper from wood preservation industry. Environ Sci Technol 31:1711-1715 (1997).

35 Hansen HK, Ottosen LM, Kliem BK, Villumsen A. Electrodialytic remediation of soils polluted with $\mathrm{Cu}, \mathrm{Cr}, \mathrm{Hg}, \mathrm{Pb}$ and $\mathrm{Zn}$. J Chem Technol Biotechnol 70:67-73 (1997).

36 Hansen HK, Ottosen LM, Laursen S, Villumsen A. Electrochemical Analysis of Ion-Exchange Membranes with Respect to a Possible Use in Electrodialytic Decontamination of Soil Polluted with Heavy Metals. Sep Sci Technol 32:24252444 (1997).

37 Donnan F. Theory of membrane equilibrium and membrane potential in the presence of nondialysing electrolytes: A contribution to physical-chemical physiology. In: Cell membrane permeability and transport. Dowden, Hutchinson \& Ross, Inc Stroundburg, PA, pp 211-222 (1979).

38 Luo T, Abdu S, Wessling M. Selectivity of ion exchange membranes: A review. $J$ Membr Sci 555:429-454 (2018).

39 Paz-Garcia JM, Schaetzle O, Biesheuvel PM, Hamelers HVM. Energy from CO2 using capacitive electrodes - Theoretical outline and calculation of open circuit voltage. J Colloid Interface Sci 418:200-207 (2014).

40 Dias-Ferreira C, Kirkelund GM, Ottosen LM. Ammonium citrate as enhancement for electrodialytic soil remediation and investigation of soil solution during the process. Chemosphere 119:889-895 (2015).

41 Gomes HI, Dias-Ferreira C, Ottosen LM, Ribeiro AB. Electrodialytic remediation of polychlorinated biphenyls contaminated soil with iron nanoparticles and two different surfactants. J Colloid Interface Sci 433:189-195 (2014).

42 Guedes P, Mateus EP, Almeida J, Ferreira AR, Couto N, Ribeiro AB. Electrodialytic treatment of sewage sludge: Current intensity influence on phosphorus recovery and organic contaminants removal. Chem Eng J 306:10581066 (2016). 
43 Kirkelund GM, Ottosen LM, Villumsen A. Electrodialytic remediation of harbour sediment in suspension-Evaluation of effects induced by changes in stirring velocity and current density on heavy metal removal and $\mathrm{pH}$. J Hazard Mater 169:685-690 (2009).

44 Nystroem GM, Ottosen LM, Villumsen A. Acidification of harbor sediment and removal of heavy metals induced by water splitting in electrodialytic remediation. Sep Sci Technol 40:2245-2264 (2005).

45 Ottosen LM, Hansen HK, Hansen CB. Water splitting at ion-exchange membranes and potential differences in soil during electrodialytic soil remediation. $J$ Appl Electrochem 30:1199-1207 (2000).

46 Choi J-H, Moon S-H. Structural change of ion-exchange membrane surfaces under high electric fields and its effects on membrane properties. J Colloid Interface Sci 265:93-100 (2003).

47 Krol JJ, Wessling M, Strathmann H. Concentration polarization with monopolar ion exchange membranes: current-voltage curves and water dissociation. J Membr Sci 162:145-154 (1999).

48 De Lara R, Rodriguez-Postigo J, Garcia-Herruzo F, Rodriguez-Maroto J, Benavente J. Decontamination of soils by membrane processes: characterization of membranes under working conditions. Ind Eng Chem Res 44:400-407 (2005).

49 Segall BA, O'Bannon CE, Matthias JA. Electro-osmosis chemistry and water quality. J Geotech Engrg Div ASCE 106:1148-1152 (1980).

50 C. Renaud P, F. Probstein R. Electro-osmotic Control of Hazardous Waste. (1987).

51 Acar YB, Gale RJ, Hamed J, Putnam G. Acid/base distributions in electrokinetic soil processing. Transp Res Rec :23-34 (1990).

52 Hamed J, Acar YB, Gale RJ. Pb(II) removal from kaolinite by electrokinetics. $J$ Geotech Eng 117:241-271 (1991).

53 Acar YB, Li H, Gale RJ. Phenol removal from kaolinite by electrokinetics. $J$ Geotech Eng 118:1837-1852 (1992).

54 Ottosen LM, Lepkova K, Kubal M. Comparison of electrodialytic removal of $\mathrm{Cu}$ from spiked kaolinite, spiked soil and industrially polluted soil. J Hazard Mater 137:113-120 (2006).

55 Reddy KR, Parupudi US, Devulapalli SN, Xu CY. Effects of soil composition on the removal of chromium by electrokinetics. J Hazard Mater 55:135-158 (1997).

56 Villen-Guzman M, Garcia-Rubio A, Paz-Garcia JM, Vereda-Alonso C, GomezLahoz C, Rodriguez-Maroto JM. Aging effects on the mobility of $\mathrm{Pb}$ in soil: Influence on the energy requirements in electroremediation. Chemosphere 213:351-357 (2018). 
57 Acar YB, Alshawabkeh AN. Electrokinetic remediation I: Pilot-scale tests with lead-spiked kaolinite. J Geotech Eng 122:173-185 (1996).

58 Lageman R, Clarke RL, Pool W. Electro-reclamation, a versatile soil remediation solution. Eng Geol 77:191-201 (2005).

59 Shapiro AP, Renaud PC, Probstein RF. Preliminary studies on the removal of chemical species from saturated porous media by electroosmosis. $P C H$ Physicochem Hydrodyn 11:785-802 (1989).

60 Acar YB, Gale RJ. US Pat 5137608 (1992).

61 USAEC. In-Situ Electrokinetic Remediation of Metal Contaminated Soils Technology Status Report. US Army Environmental Center. (2000). .

62 Ho SV, Athmer C, Sheridan PW, Hughes BM, Orth R, McKenzie D et al. The Lasagna Technology for In Situ Soil Remediation. 1. Small Field Test. Environ Sci Technol 33:1086-1091 (1999).

63 Virkutyte J, Sillanpää M, Latostenmaa P. Electrokinetic soil remediation - Critical overview. Sci Total Environ 289:97-121 (2002).

64 Hansen HK, Ottosen LM, Hansen L, Kliem BK, Villumsen A, Bech-Nielsen G. Electrodialytic remediation of soil polluted with heavy metals. Key parameters for optimization of the process. Inst Chem Eng Symp Ser :201-209 (1999).

65 Jensen JB, Kueeš V, Kubal M. Electrokinetic remediation of soils polluted with heavy metals. Removal of zinc and copper using a new concept. Environ Technol 15:1077-1082 (1994).

66 Ribeiro AB, Mateus EP, Ottosen LM, Bech-Nielsen G. Electrodialytic removal of $\mathrm{Cu}, \mathrm{Cr}$, and $\mathrm{As}$ from chromated copper arsenate-treated timber waste. Environ Sci Technol 34:784-788 (2000).

67 Hansen HK, Rojo A, Ottosen LM. Electrodialytic remediation of copper mine tailings. J Hazard Mater 117:179-183 (2005).

68 Rojo A, Hansen HK. Electrodialytic remediation of copper mine tailings: Sulphuric and citric acid addition. Sep Sci Technol 40:1947-1956 (2005).

69 Pedersen AJ, Kristensen IV, Ottosen LM, Ribeiro AB, Villumsen A. Electrodialytic remediation of CCA-treated waste wood in pilot scale. Eng Geol 77:331-338 (2005).

70 Pedersen AJ, Ottosen LM, Villumsen A. Electrodialytic removal of heavy metals from different fly ashes: Influence of heavy metal speciation in the ashes. J Hazard Mater 100:65-78 (2003).

71 Nystrøm GM, Ottosen LM, Villumsen A. Test of experimental set-ups for electrodialytic removal of $\mathrm{Cu}, \mathrm{Zn}, \mathrm{Pb}$ and $\mathrm{Cd}$ from different contaminated harbour sediments. Eng Geol 77:349-357 (2005). 
72 Ottosen LM, Jensen PE, Kirkelund GM, Hansen HK. Electrodialytic remediation of different heavy metal-polluted soils in suspension topical collection on remediation of site contamination. Water Air Soil Pollut 224 (2013) doi:10.1007/s11270-013-1707-x.

73 Ottosen LM, Jensen PE, Kirkelund GM, Dias-Ferreira C, Hansen HK. Electrodialytic remediation of heavy metal polluted soil - Treatment of water saturated or suspended soil. (2012). doi:10.3303/CET1228018.

74 Jensen PE, Ottosen LM, Ferreira C. Electrodialytic remediation of soil fines $(<63$ $\mu \mathrm{m})$ in suspension-Influence of current strength and L/S. Electrochimica Acta 52:3412-3419 (2007).

75 Sun TR, Ottosen LM, Jensen PE. Pulse current enhanced electrodialytic soil remediation-Comparison of different pulse frequencies. J Hazard Mater 237238:299-306 (2012).

76 Pedersen KB, Ottosen LM, Jensen PE, Lejon T. Comparison of 2-compartment, 3compartment and stack designs for electrodialytic removal of heavy metals from harbour sediments. Electrochimica Acta 181:48-57 (2015).

77 Kirkelund GM, Magro C, Guedes P, Jensen PE, Ribeiro AB, Ottosen LM. Electrodialytic removal of heavy metals and chloride from municipal solid waste incineration fly ash and air pollution control residue in suspension - Test of a new two compartment experimental cell. Electrochimica Acta 181:73-81 (2015).

78 Ottosen LM, Jensen PE, Kirkelund GM. Phosphorous recovery from sewage sludge ash suspended in water in a two-compartment electrodialytic cell. Waste Manag 51:142-148 (2016).

79 Guedes P, Magro C, Couto N, Mosca A, Mateus EP, Ribeiro AB. Potential of the electrodialytic process for emerging organic contaminants remediation and phosphorus separation from sewage sludge. Electrochimica Acta 181:109-117 (2015).

80 Guedes P, Couto N, Ottosen LM, Kirkelund GM, Mateus E, Ribeiro AB. Valorisation of ferric sewage sludge ashes: Potential as a phosphorus source. Waste Manag 52:193-201 (2016).

81 Pedersen KB, Jensen PE, Ottosen LM, Barlindhaug J. The relative influence of electrokinetic remediation design on the removal of $\mathrm{As}, \mathrm{Cu}, \mathrm{Pb}$ and $\mathrm{Sb}$ from shooting range soils. Eng Geol 238:52-61 (2018).

82 Chen W, Kirkelund GM, Jensen PE, Ottosen LM. Comparison of different MSWI fly ash treatment processes on the thermal behavior of $\mathrm{As}, \mathrm{Cr}, \mathrm{Pb}$ and $\mathrm{Zn}$ in the ash. Waste Manag 68:240-251 (2017).

83 Velizarova E, Ribeiro AB, Ottosen LM. A comparative study on $\mathrm{Cu}, \mathrm{Cr}$ and $\mathrm{As}$ removal from CCA-treated wood waste by dialytic and electrodialytic processes. $J$ Hazard Mater 94:147-160 (2002). 
84 Ottosen LM, Eriksson T, Hansen HK, Ribeiro AB. Effects from different types of construction refuse in the soil on electrodialytic remediation. J Hazard Mater 91:205-219 (2002).

85 Hansen HK, Ottosen LM, Villumsen A. Electrodialytic removal of cadmium from straw combustion fly ash. J Chem Technol Biotechnol 79:789-794 (2004).

86 Jakobsen MR, Fritt-Rasmussen J, Nielsen S, Ottosen LM. Electrodialytic removal of cadmium from wastewater sludge. J Hazard Mater 106:127-132 (2004).

87 Ribeiro AB, Rodríguez-Maroto JM, Mateus EP, Velizarova E, Ottosen LM. Modeling of electrodialytic and dialytic removal of $\mathrm{Cr}, \mathrm{Cu}$ and As from CCAtreated wood chips. Chemosphere 66:1716-1726 (2007).

88 Ottosen LM, Lima AT, Pedersen AJ, Ribeiro AB. Electrodialytic extraction of Cu, $\mathrm{Pb}$ and $\mathrm{Cl}$ from municipal solid waste incineration fly ash suspended in water. $J$ Chem Technol Biotechnol 81:553-559 (2006).

89 Jensen PE, Ottosen LM, Ferreira C, Villumsen A. Kinetics of electrodialytic extraction of $\mathrm{Pb}$ and soil cations from a slurry of contaminated soil fines. $J$ Hazard Mater 138:493-499 (2006).

90 Pazos M, Kirkelund GM, Ottosen LM. Electrodialytic treatment for metal removal from sewage sludge ash from fluidized bed combustion. J Hazard Mater 176:1073-1078 (2010).

91 Kirkelund GM, Damoe AJ, Ottosen LM. Electrodialytic removal of Cd from biomass combustion fly ash suspensions. J Hazard Mater 250-251:212-219 (2013).

92 Ottosen LM, Jensen PE, Kirkelund GM. Electrodialytic Separation of Phosphorus and Heavy Metals from Two Types of Sewage Sludge Ash. Sep Sci Technol Phila 49:1910-1920 (2014).

93 Guedes P, Couto N, Ottosen LM, Ribeiro AB. Phosphorus recovery from sewage sludge ash through an electrodialytic process. Waste Manag 34:886-892 (2014).

94 Pedersen KB, Lejon T, Jensen PE, Ottosen LM. Simultaneous electrodialytic removal of PAH, PCB, TBT and heavy metals from sediments. J Environ Manage 198:192-202 (2017).

95 Pedersen KB, Lejon T, Jensen PE, Ottosen LM. The influence of sediment properties and experimental variables on the efficiency of electrodialytic removal of metals from sediment. J Environ Chem Eng 5:5312-5321 (2017).

96 Zubi G, Dufo-López R, Carvalho M, Pasaoglu G. The lithium-ion battery: State of the art and future perspectives. Renew Sustain Energy Rev 89:292-308 (2018).

97 Zheng X, Zhu Z, Lin X, Zhang Y, He Y, Cao H et al. A Mini-Review on Metal Recycling from Spent Lithium Ion Batteries. Engineering 4:361-370 (2018). 
98 Energy Information Administration. Annual Energy Outlook 2012: with Projections to 2035. (2012). https://www.eia.gov/outlooks/aeo/pdf/0383(2012). pdf (accessed 13 Jun2018).

99 Zhang P, Yokoyama T, Itabashi O, Suzuki TM, Inoue K. Hydrometallurgical process for recovery of metal values from spent lithium-ion secondary batteries. Hydrometallurgy 47:259-271 (1998).

100 Etacheri V, Marom R, Elazari R, Salitra G, Aurbach D. Challenges in the development of advanced Li-ion batteries: A review. Energy Environ Sci 4:32433262 (2011).

101 Goodenough JB, Park K-S. The Li-ion rechargeable battery: A perspective. J Am Chem Soc 135:1167-1176 (2013).

102 Heelan J, Gratz E, Zheng Z, Wang Q, Chen M, Apelian D et al. Current and Prospective Li-Ion Battery Recycling and Recovery Processes. JOM 68:26322638 (2016).

103 Report on Critical Raw Materials and the Circular Economy. European Comission (2018). .

104 Winslow KM, Laux SJ, Townsend TG. A review on the growing concern and potential management strategies of waste lithium-ion batteries. Resour Conserv Recycl 129:263-277 (2018).

105 Moradi B, Botte GG. Recycling of graphite anodes for the next generation of lithium ion batteries. J Appl Electrochem 46:123-148 (2016).

106 Casimir A, Zhang H, Ogoke O, Amine JC, Lu J, Wu G. Silicon-based anodes for lithium-ion batteries: Effectiveness of materials synthesis and electrode preparation. Nano Energy 27:359-376 (2016).

107 Taiwo OO, Paz-García JM, Hall SA, Heenan TMM, Finegan DP, Mokso R et al. Microstructural degradation of silicon electrodes during lithiation observed via operando X-ray tomographic imaging. J Power Sources 342:904-912 (2017).

108 Nitta N, Wu F, Lee JT, Yushin G. Li-ion battery materials: present and future. Mater Today 18:252-264 (2015).

109 Choubey PK, Chung K-S, Kim M, Lee J, Srivastava RR. Advance review on the exploitation of the prominent energy-storage element Lithium. Part II: From sea water and spent lithium ion batteries (LIBs). Miner Eng 110:104-121 (2017).

110 Wang X, Gaustad G, Babbitt CW. Targeting high value metals in lithium-ion battery recycling via shredding and size-based separation. Waste Manag 51:204213 (2016).

111 Jha MK, Kumari A, Jha AK, Kumar V, Hait J, Pandey BD. Recovery of lithium and cobalt from waste lithium ion batteries of mobile phone. Waste Manag 33:1890-1897 (2013). 
112 Dorella G, Mansur MB. A study of the separation of cobalt from spent Li-ion battery residues. J Power Sources 170:210-215 (2007).

113 Zhang X, Xie Y, Lin X, Li H, Cao H. An overview on the processes and technologies for recycling cathodic active materials from spent lithium-ion batteries. (2013). doi:10.1007/s10163-013-0140-y.

114 Mishra D, Kim D-J, Ralph DE, Ahn J-G, Rhee Y-H. Bioleaching of metals from spent lithium ion secondary batteries using Acidithiobacillus ferrooxidans. Waste Manag 28:333-338 (2008).

115 Foster M, Isely P, Standridge CR, Hasan MM. Feasibility assessment of remanufacturing, repurposing, and recycling of end of vehicle application lithiumion batteries. J Ind Eng Manag 7:698-715 (2014).

116 Shin SM, Kim NH, Sohn JS, Yang DH, Kim YH. Development of a metal recovery process from Li-ion battery wastes. Hydrometallurgy 79:172-181 (2005).

117 Gao W, Liu C, Cao H, Zheng X, Lin X, Wang H et al. Comprehensive evaluation on effective leaching of critical metals from spent lithium-ion batteries. Waste Manag (2018) doi:10.1016/j.wasman.2018.02.023.

118 Wang R-C, Lin Y-C, Wu S-H. A novel recovery process of metal values from the cathode active materials of the lithium-ion secondary batteries. Hydrometallurgy 99:194-201 (2009).

119 Lee CK, Rhee K-I. Reductive leaching of cathodic active materials from lithium ion battery wastes. Hydrometallurgy 68:5-10 (2003).

120 Chen X, Ma H, Luo C, Zhou T. Recovery of valuable metals from waste cathode materials of spent lithium-ion batteries using mild phosphoric acid. J Hazard Mater 326:77-86 (2017).

121 Pinna EG, Ruiz MC, Ojeda MW, Rodriguez MH. Cathodes of spent Li-ion batteries: Dissolution with phosphoric acid and recovery of lithium and cobalt from leach liquors. Hydrometallurgy 167:66-71 (2017).

$122 \mathrm{Li} \mathrm{L}, \mathrm{Qu}$ W, Zhang X, Lu J, Chen R, Wu F et al. Succinic acid-based leaching system: A sustainable process for recovery of valuable metals from spent Li-ion batteries. J Power Sources 282:544-551 (2015).

123 Golmohammadzadeh R, Rashchi F, Vahidi E. Recovery of lithium and cobalt from spent lithium-ion batteries using organic acids: Process optimization and kinetic aspects. Waste Manag 64:244-254 (2017).

124 Li L, Ge J, Chen R, Wu F, Chen S, Zhang X. Environmental friendly leaching reagent for cobalt and lithium recovery from spent lithium-ion batteries. Waste Manag 30:2615-2621 (2010).

$125 \mathrm{Li} \mathrm{L}, \mathrm{Ge} \mathrm{J}, \mathrm{Wu} \mathrm{F}$, Chen R, Chen $\mathrm{S}, \mathrm{Wu}$ B. Recovery of cobalt and lithium from spent lithium ion batteries using organic citric acid as leachant. J Hazard Mater 176:288-293 (2010). 
126 Iizuka A, Yamashita Y, Nagasawa H, Yamasaki A, Yanagisawa Y. Separation of lithium and cobalt from waste lithium-ion batteries via bipolar membrane electrodialysis coupled with chelation. Sep Purif Technol 113:33-41 (2013).

127 Li L, Lu J, Ren Y, Zhang XX, Chen RJ, Wu F et al. Ascorbic-acid-assisted recovery of cobalt and lithium from spent Li-ion batteries. J Power Sources 218:21-27 (2012).

128 Gao W, Song J, Cao H, Lin X, Zhang X, Zheng X et al. Selective recovery of valuable metals from spent lithium-ion batteries - Process development and kinetics evaluation. J Clean Prod 178:833-845 (2018).

129 Bernardes A., Espinosa DC., Tenório JA. Recycling of batteries: a review of current processes and technologies. J Power Sources 130:291-298 (2004).

130 Zhang T, He Y, Wang F, Ge L, Zhu X, Li H. Chemical and process mineralogical characterizations of spent lithium-ion batteries: An approach by multi-analytical techniques. Waste Manag Asia 34:1051-1058 (2014).

131 Chen L, Tang X, Zhang Y, Li L, Zeng Z, Zhang Y. Process for the recovery of cobalt oxalate from spent lithium-ion batteries. Hydrometallurgy 108:80-86 (2011).

132 Guo Z-Y, Ji Z-Y, Chen Q-B, Liu J, Zhao Y-Y, Li F et al. Prefractionation of LiCl from concentrated seawater/salt lake brines by electrodialysis with monovalent selective ion exchange membranes. J Clean Prod 193:338-350 (2018).

133 Chen Q-B, Ji Z-Y, Liu J, Zhao Y-Y, Wang S-Z, Yuan J-S. Development of recovering lithium from brines by selective-electrodialysis: Effect of coexisting cations on the migration of lithium. J Membr Sci 548:408-420 (2018).

134 Song Y, Zhao Z. Recovery of lithium from spent lithium-ion batteries using precipitation and electrodialysis techniques. Sep Purif Technol 206:335-342 (2018). 
Table 3. Application of EDR to different solid matrices. (*options for application: a) to treat the solid as stationary or b) to treat the solid as suspension)

\section{Description}

Solid matrix

3-C a Polluted soil
Electrolytes

$0.01 \mathrm{M} \mathrm{NaNO}_{3}(\mathrm{pH}$ adjusted to 3 using $\mathrm{HNO}_{3}$ )
Target species

\section{Polluted soil}

Remediation of soil polluted with $\mathrm{Cu}$ from Wood Preservation Industry

Removal of $\mathrm{Cu}, \mathrm{Cr}$ and As from Treated Timber Waste

Removal of $\mathrm{Cu}$ from a real soil sampled at a wood preservation site in presence of different types of 3-C a construction refuse in the soil on ED.

\section{3-C a Enhancement:} addition to the soil.

3-C a Treated timber waste

Soil from a wood preservation site (Some experiments: adding a construction refuse placed in the soil).

Municipal incinerator (MSWI) fly ashes 3-C a and wood combustion fly ashes.

Removal of toxic metals from different fly ashes

Enhancement: addition of an ammonium citrate and $\mathrm{NH} 3$ mixture to the ash.

\begin{tabular}{|c|c|c|}
\hline Removal of toxic metals from straw combustion fly ash & $3-C^{a}$ & Straw combustion fly ash \\
\hline Removal of toxic metals from wastewater sludge & $3-\mathrm{C}^{\mathrm{a}}$ & Wastewater sludge \\
\hline Remediation of Copper mine tailings & $3-\mathrm{C}^{\mathrm{a}}$ & $\begin{array}{l}\text { Mine tailing } \\
\text { Enhancement: addition of citric } \\
\text { or sulphuric acid to the solid. }\end{array}$ \\
\hline Remediation of habor sediments & $3-\mathrm{C}^{\mathrm{b}}$ & Harbor sediments \\
\hline Remediation of treated waste wood in pilot scale & $3-\mathrm{C}^{\mathrm{a}}$ & $\begin{array}{l}\text { Treated waste wood } \\
\text { Enhancement: addition of } 5 \% \\
\text { oxalic acid solution or a mixture } \\
\text { of water/Na benzoate. } \\
\text { Pretreatment: Soaking step: } 5 \% \\
\text { oxalic acid, } 0.5 \mathrm{M} \mathrm{H}_{3} \mathrm{PO}_{4}\end{array}$ \\
\hline Remediation of MSWI fly ash & $3-\mathrm{C}^{\mathrm{b}}$ & MSWI fly ash \\
\hline $\begin{array}{l}\text { Remediation of polluted soil (spiked kaolinite spiked soil } \\
\text { and industrial polluted soil) }\end{array}$ & $3-\mathrm{C}^{\mathrm{a}}$ & Polluted soil \\
\hline
\end{tabular}

$0.01 \mathrm{M} \mathrm{NaNO}_{3}(\mathrm{pH}$ adjusted Toxic metals $(\mathrm{Cu}$, As)

$0.01 \mathrm{M} \mathrm{NaNO}_{3}(\mathrm{pH}$ adjusted Toxic metals $(\mathrm{Cu}, \mathrm{R}$
to 2-3 using $\mathrm{HNO}_{3}$ )

$\mathrm{Cr}, \mathrm{As}$

$0.01 \mathrm{M} \mathrm{NaNO}_{3}(\mathrm{pH}$ adjusted

to 2 using $\mathrm{HNO} 3$ )

Toxic metals $(\mathrm{Cu})$

$0.01 \mathrm{M} \mathrm{NaNO}_{3}(\mathrm{pH}<2$ using

$\mathrm{HNO}_{3}$ )

Toxic metals $(\mathrm{Cd}$,

0.25-0.5 $\mathrm{M}$ ammonium $\mathrm{Pb}, \mathrm{Zn}$ and $\mathrm{Cu}$ )

Pedersen et al. (2003) ${ }^{70}$

$0.01 \mathrm{M} \mathrm{NaNO}_{3}(\mathrm{pH}$ adjusted to 2 using $\mathrm{HNO}_{3}$ )

Toxic metals $(\mathrm{Cd})$

Toxic metals $(\mathrm{Cd})$

Hansen et al. (2004) ${ }^{85}$ using $\mathrm{HNO}_{3}$ )

Distilled water ( $\mathrm{pH}$ below 4 using $\mathrm{H}_{2} \mathrm{SO}_{4}$ at the catholyte)

$0.01 \mathrm{M} \mathrm{NaNO}_{3}(\mathrm{pH}$ below 2 Toxic metals $(\mathrm{Cu}$,
using $\mathrm{HNO}_{3}$ )

$\mathrm{Zn}, \mathrm{Pb}$ and $\mathrm{Cd})$

Jakobsen et al (2004) ${ }^{86}$

$\mathrm{NaNO}_{3}$ or oxalic acid

Toxic metals $\left(\mathrm{Cu}, \quad\right.$ Pedersen et al. (2005) ${ }^{69}$ Cr and As) Ribeiro et al. (2007) ${ }^{87}$

$0.01 \mathrm{M} \mathrm{NaNO}_{3}(\mathrm{pH}$ below 2 Toxic metals $(\mathrm{Cu}$, using $\mathrm{HNO}_{3}$ at catholyte) $\mathrm{Pb})$ and $\mathrm{Cl}$

Rojo and Hansen (2005) 68 Hansen et al (2005) ${ }^{67}$

.01 $\mathrm{M} \mathrm{NaNO}_{3}$ (pH below 2

Toxic metals $(\mathrm{Cu})$

Ottosen et al. (2006) ${ }^{88}$ using $\mathrm{HNO}_{3}$ at catholyte)
Ottosen et al. (2006) ${ }^{54}$ 


\begin{tabular}{|c|c|c|c|c|c|}
\hline Description & Cell * & Solid matrix & Electrolytes & Target species & Ref. \\
\hline Remediation of polluted soil & $3-\mathrm{C}^{\mathrm{b}}$ & Soil fines & $\begin{array}{l}0.01 \mathrm{M} \mathrm{NaNO}_{3}(\mathrm{pH} \text { between } \\
1-2 \text { using } \mathrm{HNO}_{3} \text { at catholyte } \\
\text { and } \mathrm{NaOH} \text { at anolyte) }\end{array}$ & Toxic metals $(\mathrm{Pb})$ & Jensen et al. (2006) ${ }^{89}$ \\
\hline $\begin{array}{l}\text { Recovery of toxic metals from sewage sludge ash from } \\
\text { fluidized bed combustion }\end{array}$ & $3-\mathrm{C}^{\mathrm{b}}$ & $\begin{array}{l}\text { Sewage sludge ash from } \\
\text { fluidized bed combustion }\end{array}$ & $\begin{array}{l}0.01 \mathrm{M} \mathrm{NaNO}_{3} \text { (pH below } 2 \\
\text { using } \mathrm{HNO}_{3} \text { at catholyte) }\end{array}$ & $\begin{array}{l}\text { Toxic metals }(\mathrm{Cd}, \\
\mathrm{Cr}, \mathrm{Cu}, \mathrm{Pb}, \mathrm{Ni} \text { and } \\
\mathrm{Zn})\end{array}$ & Pazos et al. (2010) ${ }^{90}$ \\
\hline $\begin{array}{l}\text { Removal of Cd from biomass combustion fly ash } \\
\text { suspensions }\end{array}$ & $3-\mathrm{C}^{\mathrm{b}}$ & Biomass combustion fly ash & $\begin{array}{l}0.01 \mathrm{M} \mathrm{NaNO}_{3} \text { (pH below } 2 \\
\text { using } \mathrm{HNO}_{3} \text { at catholyte) }\end{array}$ & Toxic metals $(\mathrm{Cd})$ & Kirkelund et al. (2013) ${ }^{91}$ \\
\hline $\begin{array}{l}\text { Separation of Phosphorus and toxic metals from sewage } \\
\text { sludge ash }\end{array}$ & $\begin{array}{l}3-\mathrm{C} \\
(1,2) \mathrm{b} \\
2-\mathrm{C}^{(3) b}\end{array}$ & $\begin{array}{l}\text { Sewage sludge ash Dissolution } \\
\text { of } \mathrm{H}_{2} \mathrm{SO}_{4}\end{array}$ & $\begin{array}{l}0.01 \mathrm{M} \mathrm{NaNO}_{3}(\mathrm{pH} \text { below } 2 \\
\text { using } \mathrm{HNO}_{3} \text { at catholyte) }\end{array}$ & $\begin{array}{l}\mathrm{P} \text { and toxic metals } \\
\text { (such as: } \mathrm{Cu}, \mathrm{Zn} \text {, } \\
\mathrm{Ni}, \mathrm{Pb}, \mathrm{Al}, \mathrm{Fe}, \mathrm{Cd} \text {, } \\
\mathrm{Cr} \text { ) }\end{array}$ & $\begin{array}{l}\text { Ottosen et al. (2014) })^{92(1)} \\
\text { Guedes et al. (2014) } \\
\text { Ottosen et al. (2016) } \\
{ }^{78(3)}\end{array}$ \\
\hline $\begin{array}{l}\text { Remediation of polychlorinated biphenyls (PCB) } \\
\text { contaminated soil with iron nanoparticles and surfactants }\end{array}$ & $2-C^{b}$ & $\begin{array}{l}\text { Soil with organic pollutants } \\
\text { Enhancements: Use of saponin } \\
\text { and Tween } 80 \text { as surfactant. }\end{array}$ & $\begin{array}{l}0.01 \mathrm{M} \mathrm{NaCl}(\mathrm{pH} \text { control } \\
\text { with } \mathrm{HCl})\end{array}$ & $\begin{array}{l}\text { Organic } \\
\text { contaminants } \\
\text { (polychlorinated } \\
\text { biphenyls) } \\
\end{array}$ & Gomes et al. (2014) ${ }^{41}$ \\
\hline $\begin{array}{l}\text { Simultaneous removal of organic pollutants and toxic } \\
\text { metals from sediments }\end{array}$ & $3-\mathrm{C}^{\mathrm{b}}$ & Sediments & $\begin{array}{l}0.01 \mathrm{M} \mathrm{NaNO}_{3} \text { (pH below } 2 \\
\text { using } \mathrm{HNO}_{3} \text { at catholyte) }\end{array}$ & $\begin{array}{l}\text { Organic } \\
\text { contaminants } \\
\text { (PAH, PCD, TBT) } \\
\text { and toxic metals } \\
(\mathrm{Cu}, \mathrm{Pb} \text { and } \mathrm{Zn})\end{array}$ & Pedersen et al. (2017) ${ }^{94,95}$ \\
\hline
\end{tabular}


Table 4. Average composition of LIBs from literature.

\begin{tabular}{|c|c|c|c|}
\hline & \multicolumn{3}{|c|}{ Concentration (wt \%) } \\
\hline & Wang et al. (2016) ${ }^{110}$ & Jha et al. $(2013)^{111}$ & $\begin{array}{l}\text { Dorella and Mansur (2017) } \\
112\end{array}$ \\
\hline \multicolumn{4}{|c|}{ Metals } \\
\hline Aluminum & 5.20 & 4.30 & 8.02 \\
\hline Cobalt & 17.30 & 23.67 & 29.49 \\
\hline Copper & 7.30 & 22.13 & 16.48 \\
\hline Iron / Steel & 16.50 & $*$ & $*$ \\
\hline Nickel & 1.20 & 0.26 & 0.02 \\
\hline Lithium & 2.00 & 2.87 & 3.14 \\
\hline \multicolumn{4}{|c|}{ Others } \\
\hline Binders & 2.40 & $*$ & $*$ \\
\hline $\begin{array}{l}\text { Carbon (no } \\
\text { graphite) }\end{array}$ & 6.00 & $*$ & $*$ \\
\hline $\begin{array}{l}\text { Electrolyte }+ \\
\text { Organic solution }\end{array}$ & 14.00 & $*$ & $*$ \\
\hline Graphite & 23.10 & $*$ & $*$ \\
\hline Plastics & 4.80 & $*$ & $*$ \\
\hline Other & Balance & Balance & Balance \\
\hline
\end{tabular}




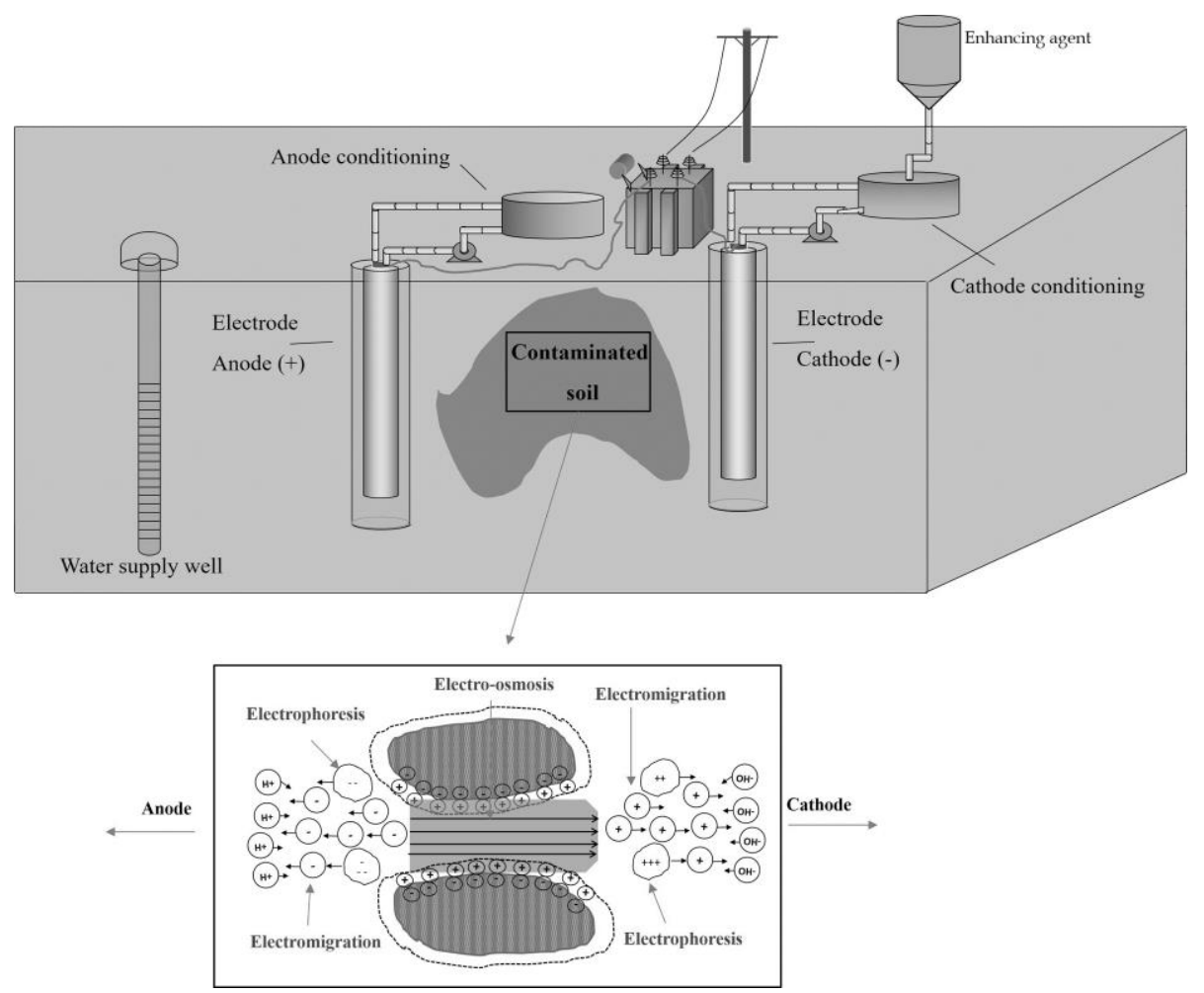

Figure 1. Electrokinetic remediation field setup. Electrochemical transport processes. 


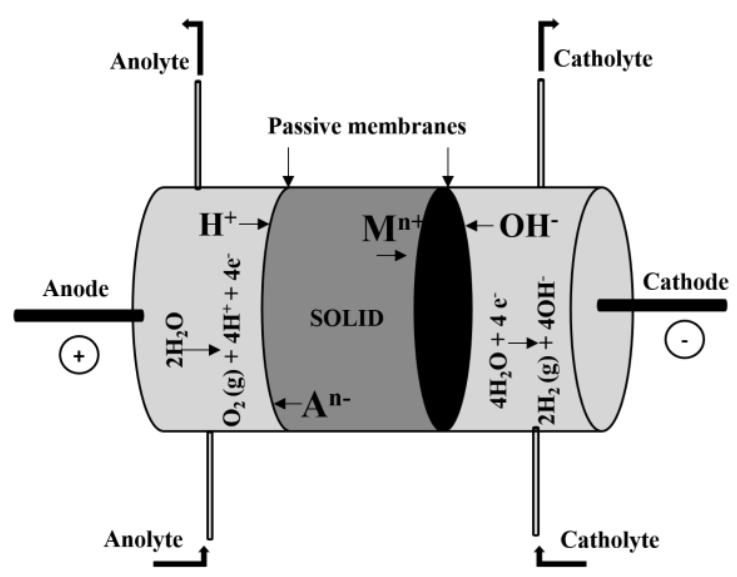

Figure 2. Schematic of the experimental cell for EKR experiments. 


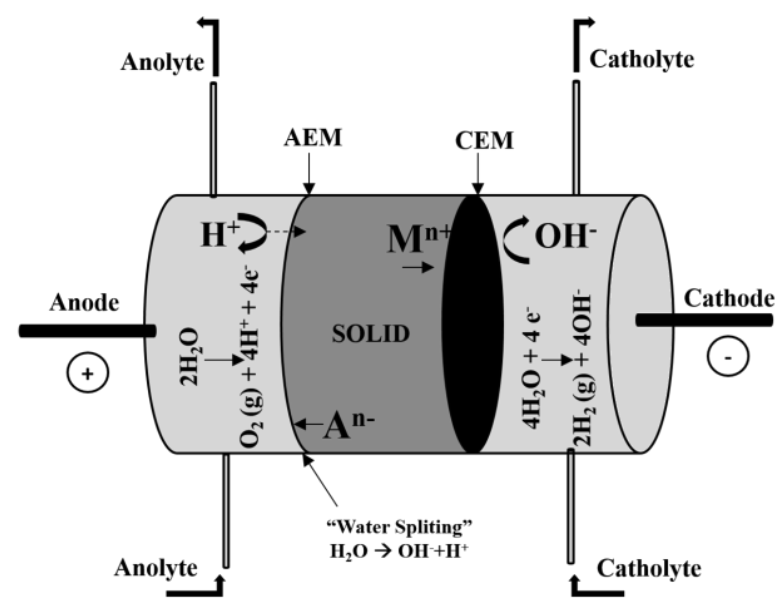

Figure 3. Schematic of the experimental cell for EDR experiments applied to a stationary, saturated solid matrix. 


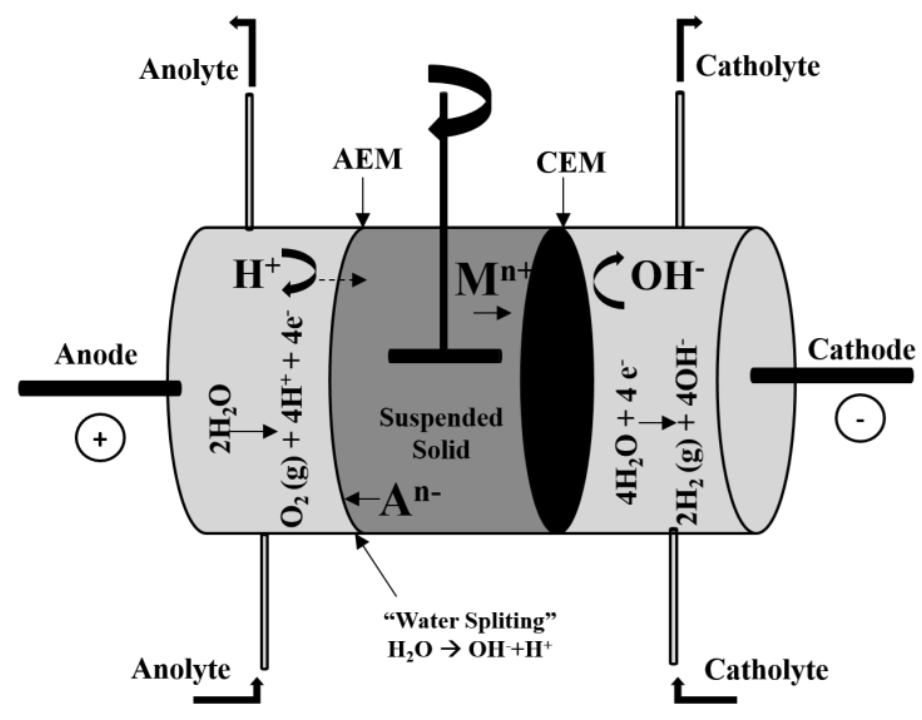

Figure 4. Schematic of the experimental 3-compartment cell for EDR experiments applied to a stirred suspension of solid. 


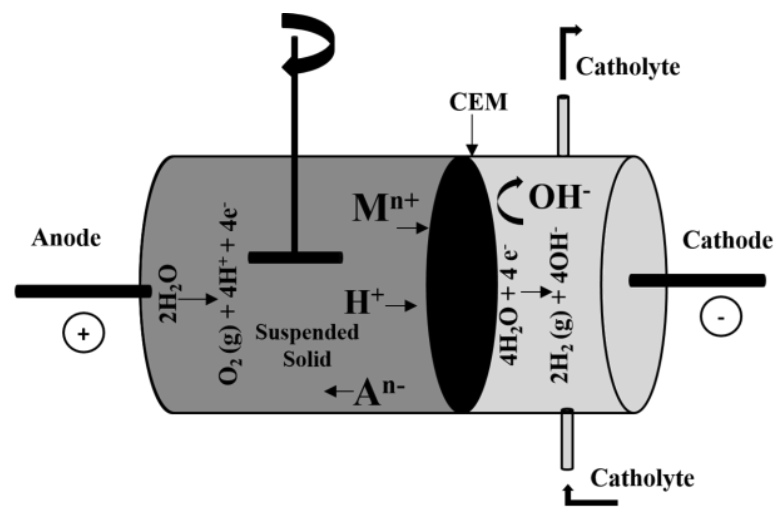

Figure 5. Schematic of the experimental 2-compartment cell for EDR experiments applied to a stirred suspension of solid. 